Please note that this version contains corrections to pages 214, 218, 219 and 303 which do not figure on the paper version. 


\section{B INTERNATIONAL TRADE IN AIR TRANSPORT: RECENT DEVELOPMENTS AND POLICY ISSUES}

\section{INTRODUCTION}

Air transport, like other transport services, is associated with international trade in two distinct ways. First, air transport is traded as a service in its own right. Second, it is a key intermediate service for many other kinds of trade, in the domain of both goods and services (such as tourism). Numerous studies have highlighted the importance of an efficient, effective and reliable air transport infrastructure, especially in developing countries, to ensure the materialization of the gains from trade (WTO, 2004). These studies also highlight the important role of international civil aviation in contributing to the development process and its role in the leisure and commercial decisions of many people. This importance is expected to increase as a result of technological innovation, deregulation and enhanced market access for foreign companies, which are all making air transport more accessible to a wider set of customers in a broader range of countries.

Despite the importance of air transport services and the fact that air transport has, for a long time, had a certain appeal to the human population, the industry appears to be in a constant struggle for survival. Media reports consistently highlight the fact that the industry is rarely profitable. When major carriers get into trouble, they make the news and when they collapse, they have widespread economic and social consequences, especially in the context of employment loss and in some cases, loss of face when it is a national carrier that folds. ${ }^{1}$

The news is, of course, not always bad. Low cost carriers (LCC), through a new business model, have made air travel more accessible both domestically and internationally in certain regions by establishing new services and servicing existing routes at a much lower cost. Also, the unveiling of the Airbus 380 aircraft in early 2005, the largest passenger aircraft in the world, is predicted to transform the industry the same way that that the Boeing 747 did 30 years earlier. ${ }^{2}$ Complementing the mechanical innovations is the rapid acceptance of the internet as a means by which air transport business can be conducted.

Government policy towards international air transport has not stood still. However, addressing the challenge of ensuring a competitive international air transport industry has not been easy. A set of wide ranging policies targeted at deregulating entry, increasing foreign ownership, liberalizing market access and easing infrastructure restrictions have been tried by a number of national governments at different levels of development. The success of these policies has varied. No unique formula exists to satisfy the sometimes conflicting goals of ensuring adequate delivery of international air transport services and profitability. Consequently, a number of outstanding issues and questions remain as to the role that the international system can play in ensuring competition.

The purpose of this essay is to review developments in the international air transport industry and examine their impact on international trade in air transport services and trade in goods and services in general. This is accomplished by, first, clarifying the mechanisms by which air transport contributes to international trade (Section 2). This is followed by a review of the economics of the international air transport system (Section 3). These two steps in the analysis are brought together in Section 4, which assesses the nature of competition in the international air transport industry and its implications for international trade.

A clear message from the analysis is that the two key policy issues facing the industry are how to ensure competition (Section 5) and to continue to debate whether or not multilateral rules on market access in international air transport would make a positive contribution to the efficient functioning of the trading system (Section 6). 


\section{INTERNATIONAL TRADE IN AIR TRANSPORT SERVICES}

The traditional approach to sectoral trade analysis is to examine the pattern, volume and value of international trade. This approach, however, is difficult for the international air transport sector, due to the paucity of data and the complexity of the industry. For example, data on the number of passengers transported from one country to another can be recorded as an import or an export, depending on the origin of the passengers and the nationality of the company that transports them. Furthermore, the expenditures of the passengers in the country where they disembark can also have balance of payments implications. Consequently, direct and indirect expenditures can be classified according to a number of categories, creating an estimation problem.

Despite these limitations, the available data on the characteristics and performance of the industry are indicative of the kinds of results that one would obtain if a full set of trade data was available. This Section, therefore, adopts a more general approach by using generic air transport data to identify the broad linkages between the industry and international trade patterns.

\section{(a) Output and performance of the industry}

The performance of the air transport industry depends on the same broad factors that determine economic performance. These include growth in gross domestic product (GDP), growth in international trade in goods and services, and growth in other industries that use air travel as a mode to transport cargo and people. In this context, the sustained economic growth experienced by the world economy in the past two decades and the strong performance of international trade has translated into a strong positive trend for international traffic.

Industry specific factors are also important in determining performance. Here, the air transport industry is no different from other industries - exogenous shocks can exert positive and negative effects on its performance. Events such as those that occurred on 11 September 2001 are an example of how an external event can have significant consequences for the industry. Similarly, the rapid rise of the use of the internet, especially for direct business to customer contact, is another example.

Chart 1 captures the overall economic performance of the industry during the past 40 years, using a number of indicators. First, overall traffic in the industry, as measured in tonne kilometres performed (TKPs) has increased steadily. ${ }^{3}$ The only two exceptions are in 1991 and 2001. Second, real yields have been declining as revenues over expenses have been static. Taken together, these two indicators, suggest that the financial performance of the industry has been fairly static in absolute terms and declining when measured in logs as in the Chart. This weak performance is against a backdrop of increases in costs of inputs, such as fuel and labour, and productivity gains.

A broader set of performance indicators, for a more recent time period and specifically for international travel are presented in Table 1. These data show that international travel, as a share of total travel, is becoming increasingly important. In 1991, international travel accounted for 23.5 per cent of all passengers carried. In 2002, this figure had risen to 34 per cent. Similar increases were recorded for passenger-kilometre data and freight-kilometre data. In aggregate, international air transport accounts for 68 per cent of the total-tonnekilometres performed by the industry. 


\section{Chart 1}

Performance of the air transport industry, 1960-2002

(Logarithm scale)

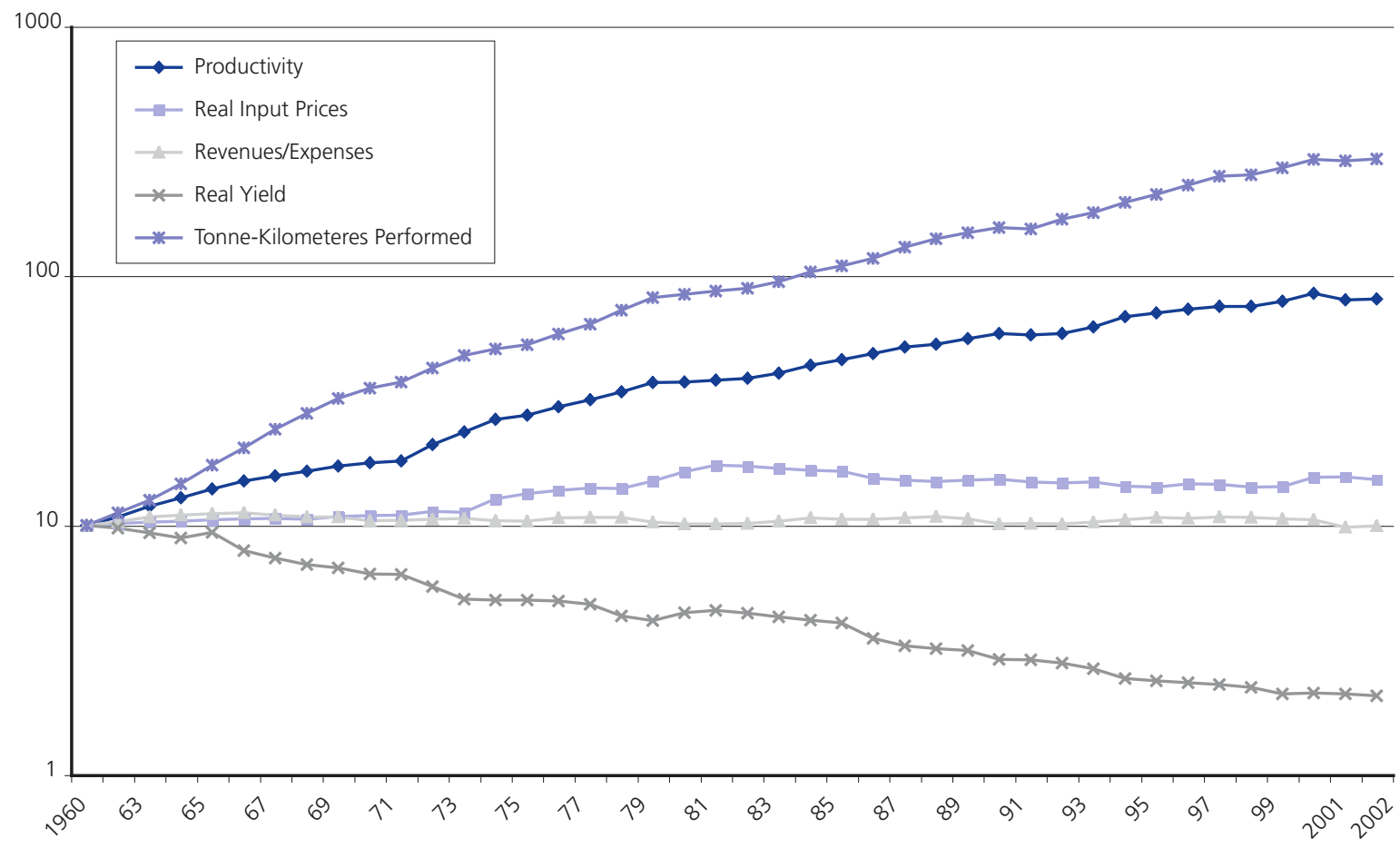

Source: ICAO.

Table 1

International output of scheduled airlines, 1991-2002

\begin{tabular}{|c|c|c|c|c|c|c|c|c|c|c|}
\hline & \multicolumn{2}{|c|}{ Passengers carried } & \multicolumn{2}{|c|}{ Passenger-kilometres } & \multicolumn{2}{|c|}{ Freight tonnes carried } & \multicolumn{2}{|c|}{ Freight-tonne kilometres } & \multicolumn{2}{|c|}{ Total tonne-kilometres } \\
\hline & Millions & $\begin{array}{l}\text { Share of total } \\
\text { (per cent) }\end{array}$ & Millions & $\begin{array}{l}\text { Share of total } \\
\text { (per cent) }\end{array}$ & Millions & $\begin{array}{l}\text { Share of total } \\
\text { (per cent) }\end{array}$ & Millions & $\begin{array}{l}\text { Share of total } \\
\text { (per cent) }\end{array}$ & Millions & $\begin{array}{l}\text { Share of total } \\
\text { (per cent) }\end{array}$ \\
\hline 1991 & 266 & 23.4 & 861530 & 46.7 & 8.5 & 48.6 & 46410 & 79.3 & 128280 & 55.6 \\
\hline 1992 & 299 & 26.1 & 982490 & 50.9 & 9.3 & 52.8 & 50750 & 81.0 & 143600 & 59.3 \\
\hline 1993 & 319 & 27.9 & 1047380 & 53.7 & 10.3 & 56.9 & 56050 & 81.9 & 155490 & 62.0 \\
\hline 1994 & 347 & 28.1 & 1143180 & 54.4 & 11.8 & 57.6 & 64700 & 83.8 & 173080 & 63.3 \\
\hline 1995 & 375 & 28.8 & 1249160 & 55.6 & 13.0 & 58.6 & 70340 & 84.6 & 189430 & 64.4 \\
\hline 1996 & 412 & 29.6 & 1380680 & 56.8 & 13.6 & 58.6 & 75510 & 84.7 & 206870 & 65.2 \\
\hline 1997 & 438 & 30.1 & 1468150 & 57.1 & 15.7 & 59.5 & 87740 & 85.3 & 227390 & 66.1 \\
\hline 1998 & 458 & 31.1 & 1512040 & 57.5 & 15.8 & 59.6 & 87050 & 85.5 & 231440 & 66.4 \\
\hline 1999 & 493 & 31.6 & 1622250 & 58.0 & 17.3 & 61.6 & 93280 & 85.8 & 247610 & 66.8 \\
\hline 2000 & 538 & 32.5 & 1778110 & 58.9 & 18.8 & 62.3 & 101520 & 86.1 & 271400 & 67.7 \\
\hline 2001 & 532 & 32.8 & 1715740 & 58.6 & 18.0 & 62.9 & 95950 & 86.7 & 259520 & 67.3 \\
\hline 2002 & 545 & 33.7 & 1732160 & 58.9 & 19.0 & 64.4 & 100590 & 86.2 & 265650 & 67.8 \\
\hline
\end{tabular}

Note: Share of total refers to the sum of domestic and international figures. Total tonne-kilometers is the aggregate of passengers, freight and mail carried.

Source: ICAO.

A noticeable feature of the data in Table 1 is the growth in international output, measured in terms of either passengers or volume. One explanation of this feature is the number of structural and regulatory changes that occurred during the 1990s. These included the combined effects of deregulation and liberalization in some major countries and the introduction of new forms of business (discussed in Section 4).

The Asia Pacific region, which accounts for a significant portion of the air transport industry, also suffered a serious setback in 2001, attributable partly to the effects of the Severe Acute Respiratory Syndrome (SARs) in China and Hong Kong, China. These effects were sufficiently severe for Cathay Pacific Airways, which is based in Hong Kong, China, to have at one point considered grounding its entire fleet. 


\section{Chart 2}

Percentage distribution total tonne kilometres of scheduled traffic according to region of airline registration, 1991-2002

1991

(1845 billion)

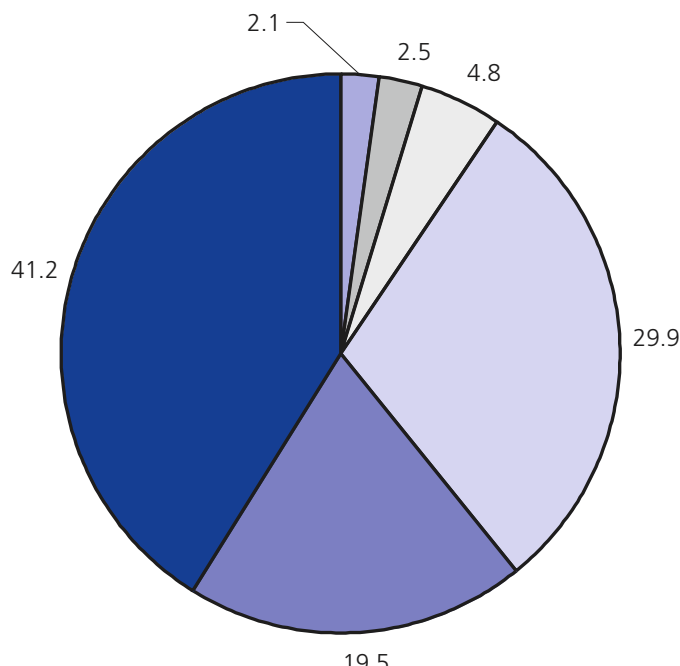

19.5
2002

(2942 billion)

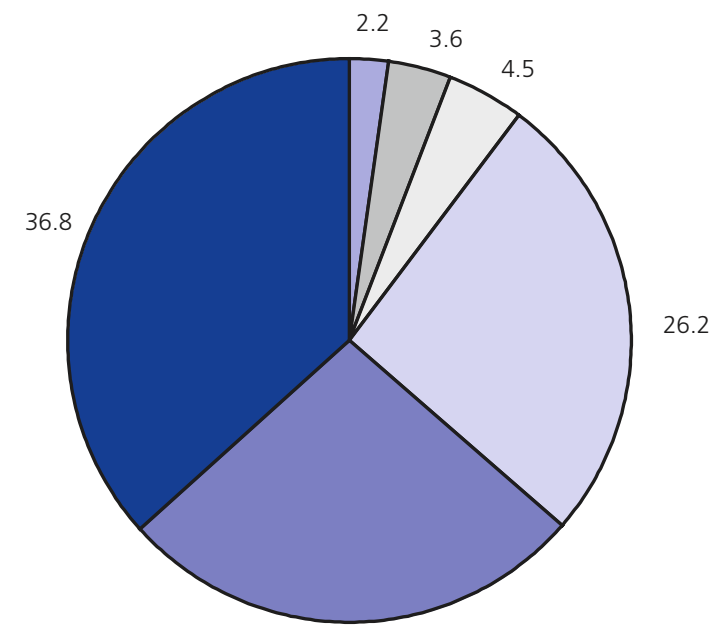

26.7

\begin{tabular}{|ll|}
\hline$\square$ Africa & $\square$ Middle East \\
$\square$ Latin America & $\square$ Europe \\
$\square$ Asia/Pacific & $\square$ North America \\
\hline
\end{tabular}

Source: WTO based on ICAO data.

Chart 2 shows the changing share of traffic by region, measured in terms of passenger traffic. In the 11 years between 1991 and 2002, the Asia Pacific region experienced the largest increase in international traffic and now accounts for a quarter of world traffic. North America, which is dominated by the United States still accounts for a third of the traffic. Although Europe's share declined, it is still 26 per cent. The remaining regions of the world account for just over 10 per cent of world traffic. Airlines from the Middle East are an example of companies that are taking advantage of the demand for international travel, relative to domestic travel. Chart 2 shows that that region has increased its share of world traffic from 2.5 per cent to 3.6 per cent.

The strong concentration in air transport across the three regions is also reflected in the direction of travel. Table 2 shows that the most travelled international route is the North Atlantic, which accounts for approximately 19.2 per cent of total international traffic. The next two most important routes, between Europe and Asia/ Pacific and within the Asia/Pacific region, account, respectively, for 16.5 per cent and 13 per cent.

Table 2 also provides data on the operating and financial characteristics of the different routes. It indicates that the larger aircraft are utilized on routes with larger shares of traffic and longer flight stages. For example, in 2002 the busiest route, with an average length of 5737 kilometres, is serviced with aircraft with an average of 258 seats. The route with the largest average number of seats is the North/Mid-Pacific route, which also has the longest length of flight stage. That route also has one of the lowest passenger costs per passenger kilometres.

The figures in Chart 2 and Table 2 are a strong indication that the demand for air transport depends significantly on per capita GDP. The regions with the higher per capita GDP, Europe and North America, account for almost two-thirds of world traffic. Furthermore, the Asia Pacific region, which experienced the highest GDP growth rates and trade growth rates during the 1990s, have increased their share of traffic markedly. 


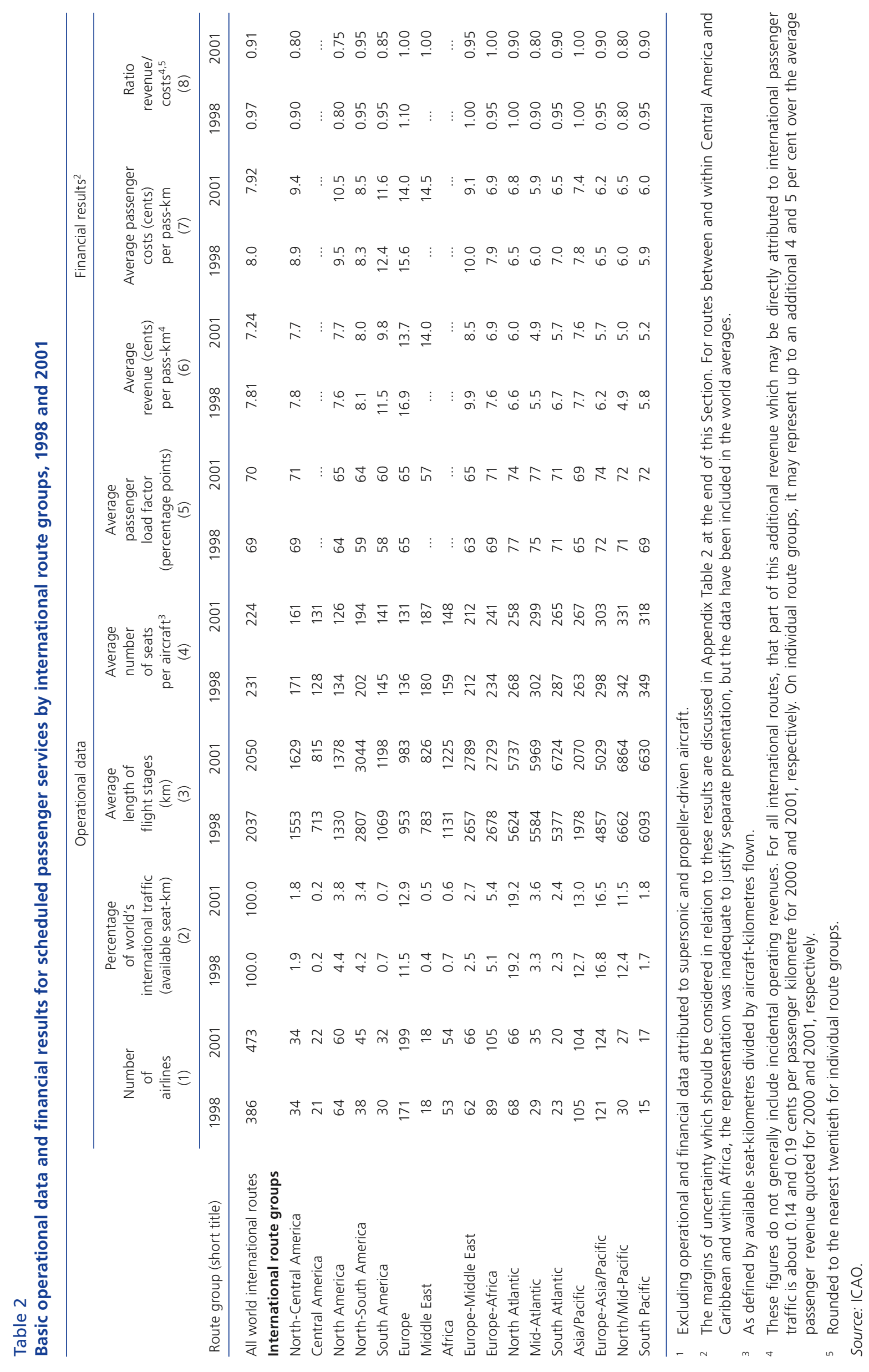

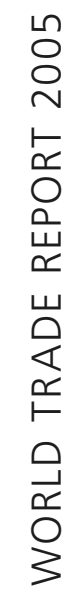

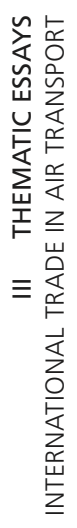

ص 
Table 3

Leading traders in international air transport, 2002

\begin{tabular}{|c|c|c|c|c|c|c|c|c|}
\hline & \multicolumn{2}{|c|}{ Passenger } & \multicolumn{2}{|c|}{ Freight } & \multicolumn{2}{|c|}{ Other } & \multirow[b]{2}{*}{ Total } & \multirow{2}{*}{$\begin{array}{c}\text { Air transport as } \\
\text { percentage of total } \\
\text { commercial services trade }\end{array}$} \\
\hline & $\begin{array}{c}\text { Dollars } \\
\text { (Millions) }\end{array}$ & $\begin{array}{c}\text { percentage } \\
\text { of total }\end{array}$ & $\begin{array}{c}\text { Dollars } \\
\text { (Millions) }\end{array}$ & $\begin{array}{c}\text { percentage } \\
\text { of total }\end{array}$ & $\begin{array}{c}\text { Dollars } \\
\text { (Millions) }\end{array}$ & $\begin{array}{c}\text { percentage } \\
\text { of total }\end{array}$ & & \\
\hline \multicolumn{9}{|l|}{ Exports } \\
\hline Extra-EU (15) & 18967 & 63 & 4280 & 14 & 6639 & 22 & 29894 & 10 \\
\hline USA & 16291 & 74 & 5787 & 26 & n.a & n.a & 22078 & 8 \\
\hline Japan & 2561 & 33 & 2287 & 29 & 3018 & 38 & 7867 & 12 \\
\hline Canada & 2021 & 64 & n.a & n.a. & 1145 & 36 & 3165 & 8 \\
\hline Russia & 1142 & 53 & 486 & 22 & 534 & 25 & 2161 & 16 \\
\hline Taipei, Chinese & 486 & 26 & 1306 & 70 & 78 & 4 & 1870 & 9 \\
\hline China & 1114 & 67 & 539 & 33 & n.a & n.a. & 1653 & 4 \\
\hline Malaysia & 966 & 81 & 163 & 14 & 69 & 6 & 1198 & 8 \\
\hline Mexico & 689 & 68 & n.a & n.a. & 327 & 32 & 1016 & 8 \\
\hline Pakistan & 465 & 72 & 50 & 8 & 128 & 20 & 643 & 43 \\
\hline Israel & 281 & 54 & 127 & 24 & 114 & 22 & 522 & 5 \\
\hline \multicolumn{9}{|l|}{ Imports } \\
\hline Extra-EU (15) & 14066 & 54 & 3046 & 12 & 9095 & 35 & 26147 & 9 \\
\hline USA & 19189 & 80 & 4878 & 20 & n.a & n.a. & 24067 & 11 \\
\hline Japan & 8309 & 74 & 1994 & 18 & 962 & 9 & 11265 & 11 \\
\hline Canada & 2398 & 64 & 1352 & 36 & n.a & n.a. & 3749 & 8 \\
\hline China & 1308 & 37 & 2190 & 63 & n.a & n.a. & 3498 & 8 \\
\hline Taipei, Chinese & 1224 & 59 & 262 & 13 & 591 & 28 & 2077 & 9 \\
\hline Mexico & 1027 & 52 & 270 & 14 & 676 & 34 & 1973 & 12 \\
\hline Russia & 271 & 22 & 559 & 45 & 401 & 33 & 1230 & 5 \\
\hline Israel & 773 & 64 & 83 & 7 & 345 & 29 & 1201 & 11 \\
\hline Malaysia & 712 & 74 & n.a & n.a. & 249 & 26 & 961 & 6 \\
\hline Argentina & 388 & 67 & 74 & 13 & 113 & 20 & 575 & 13 \\
\hline
\end{tabular}

Source: WTO based on IMF and Eurostat data. Refers only to economies that report these data.

A country breakdown of total and international traffic for 1993 and 2003 is provided in Appendix Table 1. It shows that the United States ranks first in every category and that seven of the top ten countries in terms of total tonne-kilometres performed (TKP) are developed countries. The importance of the US to the global air transport industry is illustrated by the fact that its total TKP is nearly six times larger than Germany, the second ranked country. In terms of international TKP and passenger kilometres performed (PKP) the United States posted figures twice as large as those of the second ranked countries. ${ }^{4}$

A number of observations about the interests of different countries in international air travel can also be made about the data in Appendix Table 1. The first is the importance of the domestic market to geographically large countries. For example, in the United States, international TKP accounts for only 33 per cent of total TKP and international PKP accounts for 25 per cent of total PKP. Similarly, international TKP and PKP for Australia are 63 and 56.8 per cent respectively and for Canada they are 61.5 and 57.6 per cent respectively. This pattern is not specific to developed countries. Similar figures are reported for Brazil, India and China.

In contrast, small economies report very low domestic figures and very high international figures. Hong Kong, China and Singapore are at the extreme in this regard. As city states, their domestic market is non-existent. Nevertheless, the demand for air travel in these economies is such that even on the basis only of international figures, both rank in the top 10 in the world in terms of either TKP or PKP.

The concentration of global air transport traffic in East Asia, North America and Western Europe is reflected in their dominance in the rankings of airlines in terms of passenger traffic (Appendix Table 2) and in cargo (Appendix Table 3). Current available forecasts of international travel indicate that this concentration will continue (Appendix Table 4).

4 For international TKPs the second ranked country was Germany and for international PKP the second ranked country was the United Kingdom. 


\section{(b) International trade in air transport services}

Air transport can have direct and indirect impacts on international trade, since it covers all air transportation services that are performed by residents of one economy for those of another, involving the carriage of passengers, the movement of goods (freight), rentals (charters) of carriers with crew, and related supporting and auxiliary services. ${ }^{5} \mathrm{~A}$ threefold classification, which distinguishes between passenger, freight and other transactions is used.

Passenger services covers all services transacted between two foreign economies in the international transportation of non-residents by resident carriers and that of residents by non-resident carriers. Passenger services performed within an economy by non-resident carriers such as fares that are part of a package are also included in this definition. ${ }^{6}$ Freight services are calculated on the basis of costs incurred to export or import goods through air transport. This includes the freight involved in other countries as long as the freight originates or is delivered in the reporting economy. All other transactions that are not listed in passenger or freight are included in the other category.

The indirect impact of air transport is captured in two ways. The first is through expenditure by non-residents on goods and services purchased in a foreign economy. This component, which is most commonly associated with tourism, can be facilitated through air transport, or other modes of travel. The second is through expenditure on goods related to the air transport industry, but not directly linked to the movement of persons.

Although the collection of data on international trade in air transport is still in its infancy, the available data show that air transport is an important component of world trade. Table 3 presents data on imports and exports of air transport as they relate directly to services trade. Indirect trade through the travel category and expenditures that can be classified as being on goods is ignored. When the available data are aggregated, air transport can be shown to account for approximately 10 per cent of world trade in services. For some developing countries, such as Pakistan, air transport accounts for as much as 43 per cent of services exports.

One of the most noticeable features of the Table is the dominance of the EC and the United States in both imports and exports. The Table also shows that passenger traffic is by no means the dominant aspect of international trade in air transport for all countries. While it accounts for as much as 81 per cent of total air transport exports for Malaysia, the same figure for Japan is 33 per cent and for Chinese Taipei is 26 per cent. Similarly varying figures can also be found in the import data. Passenger traffic is only 54 per cent of ECs total air transport imports, but the figure is 80 per cent for the United States.

The figures in Table 3 refer to aggregate trade in services. In this context, the role of small developing countries, such as the 50 countries classified by the United Nations as Least-Developed, may seem limited. In reality, however, air transport is extremely important to them as a means by which they can export their tourism services and their products.

The importance of air transport for tourism is illustrated by the fact that in 2000 half of the total international arrivals for tourists in Africa arrived by air (ATAG, 2003). The comparable figure for Latin America and the Caribbean is 55 per cent (ATAG, 2003). This figure indicates very clearly that developments in the air transport sector have direct implications for the tourism industry.

Some related items that are excluded from transportation services are freight insurance (included in insurance services); goods procured in ports by non-resident carriers and repairs of transportation equipment (both are treated as goods, not services); repairs of railway facilities, harbours, and airfield facilities (included in construction services); and rentals or charters of carriers without crew (included in operational leasing services).

6 Other items included in this definition are charges for excess baggage, vehicles, or other personal accompanying effects; expenditures on food, drink, or other items passengers purchase on board carriers; and passenger services such as rentals of aircraft. 
The other mechanism by which air transport affects international trade is through the carriage of cargo. One estimate is that 40 per cent of the value of world merchandise trade and 2 per cent of its volume is carried by air (OECD, 1999). Furthermore, the daily shipment of air freight in 2004 reached 1.9 million tons, which is three times higher than the value in 1992, with an average annual growth of 11.1 per cent.?

These figures make intuitive sense, since it would be more profitable to ship products that have the dual characteristics of being time sensitive and that have a high value to weight ratio via air. Such products include electronic items and high tech instruments. Also, a recent development which is extremely important to developing countries is the use of air freight to export cut flowers, live trees/plants and fish (OECD, 1999). Air freight has allowed many developing countries to have access to distant markets in a more timely fashion. Kenya, Zimbabwe and Zambia, for example, export their fresh vegetables and horticultural products by air to Europe. Similarly, countries in the South Pacific use air freight to access customers in Australia, Japan and the United States.

\section{ECONOMICS OF THE AIR TRANSPORT INDUSTRY}

The air transport industry possesses a number of structural characteristics which determines its performance. First and foremost among these is the set of barriers to entry, both structural and regulatory. Second is the nature of competition itself - transporting passengers or cargo from one destination to another involves a number of choices, not the least of which is the pair of destinations to service (or routes). Once this is done, the capacity of the aircraft needs to be selected, as well as the frequency of the flights. This Section presents an overview of some of the main economic aspects of the industry.

\section{(a) Market structure}

The air transport industry, like other similar industries such as maritime transport and telecommunications, depends to a degree on fixed costs in order to operate. ${ }^{8}$ Fixed costs are expenditures that need to be incurred prior to the delivery of a service and are independent of output. Once these costs have been incurred the average cost of producing output will decrease as output increases.

Fixed costs can partly explain why certain pairs of destinations are served. ${ }^{9}$ Since a firm has to invest in capacity in order to provide a service, it will do so only in markets or city pairs where there is a sufficient market. They can, under certain circumstances, also act as a structural barrier to entry, since incumbent firms that have already incurred fixed costs and have large levels of output will be able to produce at a lower per unit cost.10 A related factor associated with declining average costs is the density, or size of the market. A city-pair with a low level of traffic can be serviced more efficiently with smaller aircraft. In contrast, a city-pair with more dense traffic could be serviced with a larger aircraft that could provide the service at a lower cost per seat.

The air transport industry is large and diverse and encompasses firms of all sizes. Most people are familiar with the large airlines that fly the large aircraft. In reality, there are over 900 airlines operating, some of which fly only small aircraft over small distances. Regardless of the volume of traffic (either cargo or passenger), the existence of fixed costs can, but not always, act as a deterrent to entry, thereby reducing the number of operating firms that would otherwise be in the market.

\footnotetext{
These figures are published by the Air Cargo Management Group, www.cargofacts.com, 31 December 2004.

8 It is also important to take into account the reversibility of the fixed costs. In cases where the fixed costs cannot be recovered (called sunk costs), such costs are more likely to act as a barrier to entry.

9 This is assuming a homogenous product. Product differentiation will be discussed below in the context of competition

10 It should be noted, however, that in many cases aircraft are leased and not owned by airlines. This means that airlines need not be tied down by the costs of the aircraft and can expand and contract their fleet in response to demand conditions, depending on the terms of their lease.
} 
Not surprisingly, much of the focus and analysis is on the nature of competition in the markets where large national carriers have been operating for a considerable length of time. This analysis typically isolates the oligopolistic behaviour of the firms. But, as is now well known, the number of firms in a market may not necessarily be an accurate indicator of competition. Even markets with a small number of firms could be "contestable" if the level of entry barriers is low.

On the demand side it is important to note that consumers often have particular requirements, relating to such matters as the time of delivery, either in terms of the specific day, the time of day, or the specific time of the year. For example, a ticket between any two international city pairs is typically more in demand during holiday seasons such as Christmas, or during the summer break in either hemisphere. Therefore, the varied nature of demand is an important determinant of the output of the industry.

\section{Chart 3}

Distribution of operating revenues and expenses, 2002
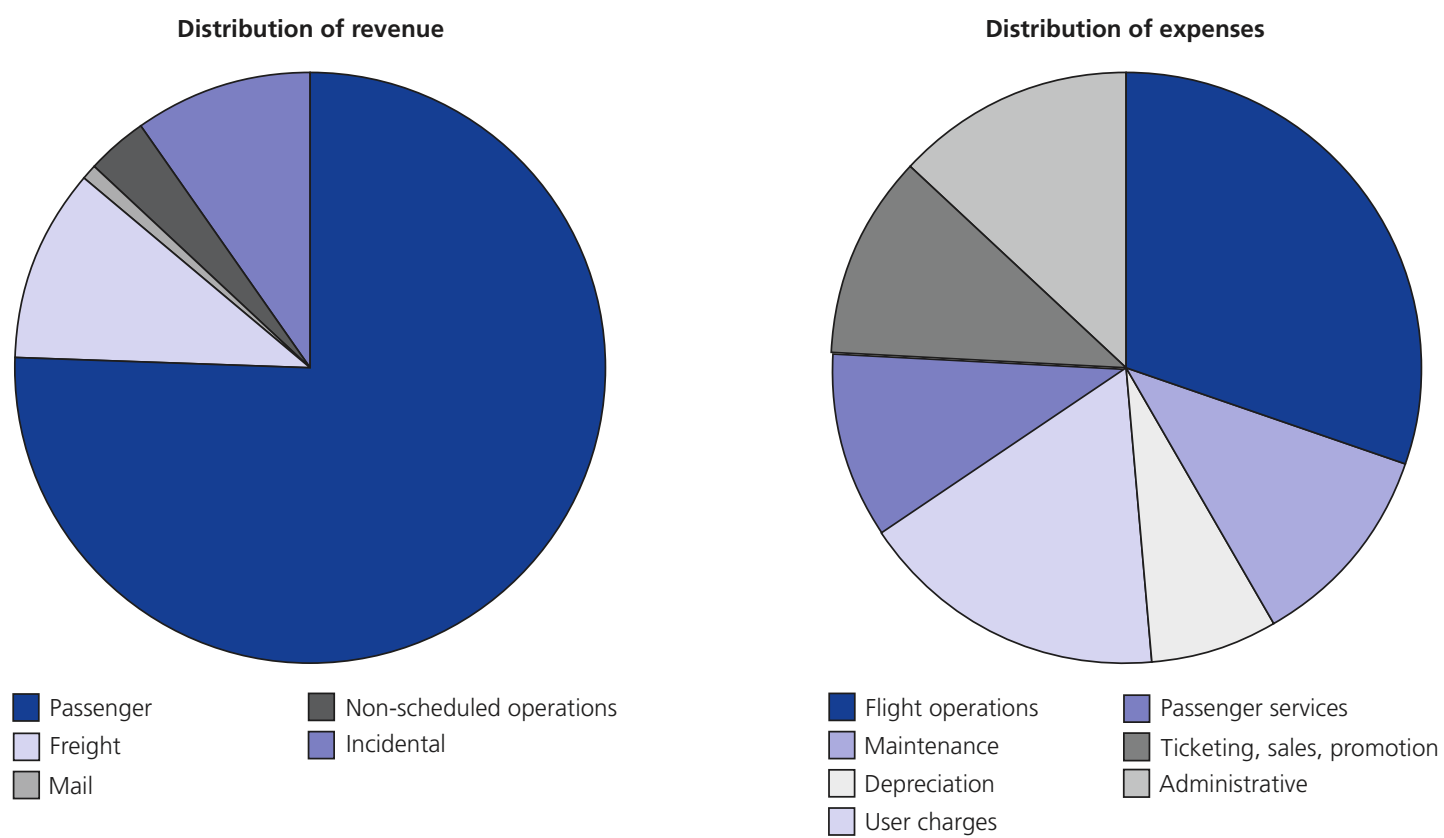

Source: ICAO.

The price elasticity of demand is an indicator that is often used to differentiate between types of demand."1 Table 4 summarizes elasticity values from a wide variety of studies in different segments of the market for air transport services. The results indicate that the median values correspond to the fact that demand differs across consumers and also by type of flight. In general, the demand for business class is price inelastic and more inelastic than economy class, except for long-haul domestic business class (Canada, 2001). It should be noted that these studies were conducted at different points in time, using different sample sizes and for different markets.

With respect to the cost side, Chart 3 indicates that over time the aggregate cost structure of airlines has not changed much, although it may have for specific airlines. Flight operations, including the cost of aircraft and running expenses are approximately 45 per cent of total costs. Ground costs, or indirect costs account for the remainder of the expenses. The two most public aspects of the cost structure of airlines are fuel and labour. Although labour is not listed separately in Chart 3, some estimates suggest that it accounts for almost 40 per cent of total costs. Therefore, as fuel prices increase, or pressures on profitability arise, airlines not surprisingly seek to reduce labour costs in conjunction with increased productivity.

11 The price elasticity of demand is defined as the percentage change in quantity demanded caused by a one per cent change in price. Since the demand curve, which measures the relationship between price and quantity demanded is negatively sloped, the value of the price elasticity of demand is always negative. Accordingly, only the absolute value of the price elasticity of demand is important. Demand is said to be price elastic if the value is greater than one, inelastic if it is less than one and unit elastic if it is equal to one. 
Table 4

Summary of absolute elasticity values

\begin{tabular}{|c|c|c|c|c|}
\hline \multirow{3}{*}{ Category } & \multicolumn{2}{|c|}{$\begin{array}{c}\text { Elasticity Values } \\
\text { All Studies }\end{array}$} & \multicolumn{2}{|c|}{$\begin{array}{c}\text { Elasticity Values } \\
\text { Passing grade studies }\end{array}$} \\
\hline & \multicolumn{2}{|c|}{ Median } & \multicolumn{2}{|c|}{ Median } \\
\hline & (1st quartile) & (3rd quartile) & (1st quartile) & (3rd quartile) \\
\hline \multirow{2}{*}{ Own-price: Long-haul international business } & \multicolumn{2}{|c|}{0.265} & \multicolumn{2}{|c|}{0.265} \\
\hline & 0.475 & 0.198 & 0.475 & 0.198 \\
\hline \multirow{2}{*}{ Own-price: Long-haul international leisure } & \multicolumn{2}{|c|}{0.993} & \multicolumn{2}{|c|}{1.040} \\
\hline & 1.65 & 0.535 & 1.700 & 0.560 \\
\hline \multirow{2}{*}{ Own-price: Long-haul domestic business } & \multicolumn{2}{|c|}{1.150} & \multicolumn{2}{|c|}{1.150} \\
\hline & 1.428 & 0.836 & 1.428 & 0.836 \\
\hline \multirow{2}{*}{ Own-price: Long-haul domestic leisure } & \multicolumn{2}{|c|}{1.120} & \multicolumn{2}{|c|}{1.104} \\
\hline & 1.472 & 0.887 & 1.228 & 0.787 \\
\hline \multirow{2}{*}{ Own-price: Short/medium-haul leisure } & \multicolumn{2}{|c|}{1.520} & \multicolumn{2}{|c|}{1.520} \\
\hline & 1.745 & 0.885 & 1.743 & 1.288 \\
\hline \multirow{2}{*}{ Own-price: Short/medium-haul business } & \multicolumn{2}{|c|}{0.730} & \multicolumn{2}{|c|}{0.700} \\
\hline & 0.798 & 0.608 & 0.783 & 0.595 \\
\hline \multirow{2}{*}{ Income Elasticity } & \multirow{2}{*}{\multicolumn{2}{|c|}{1.390}} & \multicolumn{2}{|c|}{1.140} \\
\hline & & & 0.807 & 2.0489 \\
\hline
\end{tabular}

Source: Industry Canada.

Note: Passing grade studies are studies, wich the authors deem to have passed certain academic quality criteria (http://www.fin. gc.ca/consultresp/Airtravel/airtravStdy_e.html).

\section{(b) Technology}

Although all industries are impacted by technological change, few are affected more so than the air transport industry. The travelling public can now readily identify with booking air tickets on the internet, or checking the delivery date of the package that they are expected to send or receive. One of the most significant and tangible impacts of technology has been the evolution of the capacity and range of the aircraft. In 1935, the most modern aircraft in commercial service was the Douglas Corporation DC-3, which had a speed of $346 \mathrm{~km} / \mathrm{hr}$ and a range of 563 kilometres. Since then, a number of aircraft were developed that changed not only the industry, but people's lives. For example, in the immediate post-World War II era the dominant plane was the Lockheed Constellation that cut the time to travel from one coast of the United States to the other to under seven hours. This revolutionalized the industry, but the Constellation's performance gave way to the jet age and the Boeing 707. The spectacular pace of technological development continued through to the early 1970s when, arguably, the most visible and famous aircraft of all, the Concorde, entered service. This supersonic aircraft created a new era for air travel, but ended when the plane was taken out of active service in 2003. In 2006 the largest commercial aircraft, the Airbus A380, is expected to enter into service with a seating capacity of 555 . It will also have a range of $14,500 \mathrm{kms}$.

A key aspect of the development of new aircraft has been the ability to lower the cost of air travel and increase its accessibility to a wider set of consumers. This has been achieved through two mechanisms. First, through more fuel efficient and otherwise cost-effective aircraft. Second, by changing the composition of the fleet. A broader choice of aircraft types has made it easier for airlines to penetrate different international markets.

When air travel first commenced it was limited only to the wealthy. As the cost of air travel continues to decline relative to other modes of transport, such as rail and road transport, it will broaden its customer base. This issue will be taken up in the next Section, which examines competition in the air transport industry.

Technological developments have not been limited to the speed, range and capacity of aircraft. In recent years, one of the most influential technological developments in the industry was the strengthening of business to customer links through the internet. Four different approaches to exploiting the advantages of information technology can be identified (ICAO, 2003): 
- Websites established by travel agents as an extension of their normal services;

- Website travel agents that do not have conventional "bricks and mortar" outlets;

- Websites managed by groups of airlines;

- Websites of the airlines themselves.

Each of these channels have been effective when measured in terms of their share of total ticket sales. Some airlines have relied exclusively on the internet to sell their tickets. These airlines, called Low Cost Carriers (LCC) sell a significant share of their total sales through the internet. This results in a saving in the distribution costs of tickets as well as strengthening the links between the company and the customer.

Perhaps the most significant aspect of increased ticket sales through the internet has been the impact on increased transparency in ticket pricing. As noted in Table 4, the demand for leisure tickets is price elastic. Therefore, leisure customers have an incentive to search out the lowest cost ticket. The internet allows for a quick and easy comparison of prices, which forces airlines to be more transparent and more competitive in the price offerings.

Travel agents have also been forced to become more transparent in terms of their fees. The growth of internet has resulted in airlines reducing and in some cases eliminating the commissions paid to travel agents. As a result, customers now pay travel agents directly for the services they provide. This change may induce further substitution away from the traditional bricks-and-mortar service provided by travel agents.

\section{(c) Infrastructure}

International air transport is a complex industry, whose success and efficiency depends upon a range of factors, including government policy. The transport of people and cargo are only one component of the sector. The sector also includes various ancillary services, such as airport, ground handling, leasing and catering. Furthermore, the industry must also take into account the negative effects that it has on the environment. This Section examines how the management of airports and environmental considerations affect the performance of the industry.

\section{(i) Airports}

The location of airports and the availability of landing slots are fundamental determinants of which routes airlines choose to service. Furthermore, as indicated in Chart 3, airport charges are an important component of total air carrier expenses, accounting for approximately 4 per cent of total costs.

Given the continued growth in air traffic, capacity constraints at a number of airports has become an issue over the past decade. A number of high growth international ports, such as Hong Kong, China (1998), Osaka (1994), Kuala Lumpur (1998) and Shanghai (2002) have built new airports to deal with the problem. Capacity expansion possibilities for a number of major ports are limited, however, creating a congestion problem. ${ }^{12}$ Some of these limitations include environmental, physical and other constraints. London's Heathrow airport is particularly notable for the capacity constraint problem. After decades of struggling to deal with congestion, the authorities have decided to build a new terminal and a short runway. ${ }^{13}$ Nevertheless, the allocation of landing/takeoff slots at Heathrow, as at other airports, has direct competition policy implications. A number of airlines have made increasing use of secondary airports in order to circumvent the problem of congestion.

In the absence of capacity expansion, the only way to address airport congestion is through a mechanism for slot allocation. If such a mechanism is not efficient and transparent, slot allocation could create an anticompetitive environment by favouring certain carriers. One mechanism used in international air transport is the IATA Airline Schedule Coordination Conference, but this is voluntary. This mechanism is widely used. The only notable exception is some airports in the United States for the allocation of international slots.

12 Some of these new airports have taken advantage of changes in land-use in order to construct their airport, while others such as Hong Kong, China have had to undertake land reclamation projects. The Osaka airport is built 5 kilometers from shore in 20 meters of water.

13 The United Kingdom approach to handling the airport capacity problems is detailed in the White Paper entitled The Future of Air Transport, 16 December 2003 http://www.dft.gov.uk/ 


\section{(ii) Environment}

Isolating how much of the air transport environmental footprint is associated specifically with international traffic is difficult. This depends upon a variety of factors, such as the location of airports, the size of aircraft, the age of aircraft and flight schedules. Traffic between large international airports is characterized by larger long-range aircraft, which are louder and have greater emissions than smaller aircraft. In general, however, newer aircraft are estimated to be 70 per cent more fuel efficient than 30 years ago. For example, the two newest passenger aircraft destined to service predominantly international routes, the Boeing $787^{14}$ and the Airbus A380, are boasting the smallest environmental footprint of any aircraft to date.

Specific environmental issues associated with the air transport industry come under two broad headings - flight operations and ground operations. In terms of flight operations, the two main issues are emissions arising from the combustion of aviation fuel and noise. ${ }^{15}$ In terms of ground operations, these are noise, traffic congestion, land use and waste.

Air transport, both domestic and international, has a local and global impact on the environment. Local impacts include aircraft noise and air noise problems. The construction of new airports or airport expansion will obviously exacerbate the problem. A global environmental impact relates to fuel use. The environmental effects of air transport services are not limited to flight and ground operations. They can include the environmental damage arising from the manufacture of aircraft. ${ }^{16}$

The air transport industry, however, is not unique in having to address environmental sustainability issues. The approach that appears to have been adopted across the industry is one that is consistent with a more general acceptance that environmental considerations must be taken into account in the context of all economic activity.

\section{(d) Regulatory environment}

\section{(i) Domestic regulation}

The immediate post World War II regulatory environment for air transport was one of very strict government controls on entry and firm behaviour. International routes, as well as capacity and tariffs to be charged, were highly regulated. Since then, a clear and unambiguous trend in the domestic and international air transport industry has been towards deregulation and liberalization. This Section reviews some relevant trends in the industry in the domestic context, which have been an important driver of change in the international sphere. The various approaches that have been adopted to govern the industry at the international level are discussed in Subsection 6.

In the past, the domestic airline sector in many countries was subject to extensive regulation of fares, entry and exit (Button, 1990). This reflected a prevailing view that competition in this sector was unworkable or inherently unstable. Evidence also suggests that, in many cases, regulation responded to political pressures from incumbent carriers seeking to limit entry and maintain higher-than-competitive fares (Stigler, 1971; Jordan, 1972). In any case, in the 1970 s and 1980 s the prevailing approach to regulation was increasingly questioned. Economic studies documented the costs that regulation entailed (Jordan, 1970; Douglas and Miller, 1974; Findlay, 1985; Jordan, 1982) and made the case that competitive markets subject to minimal regulation were a viable and preferable alternative (Douglas and Miller, 1974; Economic Council of Canada, 1981).

One of the first countries to liberalize its domestic market was the United States, which adopted the Airline Deregulation Act in 1978. This legislation largely eliminated controls on entry, exit and pricing in the US domestic airline sector. The statutory test to be met for carriers to enter new markets was changed from the

$14 \quad$ Until 28 January this model was referred to as the 7E7.

15 Aircraft emissions include carbon dioxide, nitrogen oxides, sulphur dioxide, unburned hydrocarbons and water vapour. All of these have local and/or global environmental effects.

16 Boeing and Airbus each publish environmental statements on their websites; www.boeing.com and www.airbus.com, which indicate the extent to which they take environmental considerations into account in their production techniques. 
pre-existing restrictive one of "public convenience and necessity" to the more liberal standard of "fit, willing and able". Whereas the former had served as an effective barrier to entry, under the latter new entrants were required simply to establish their financial and operational competence. This led to extensive competitive entry and far-reaching structural changes in the US domestic airline sector. Some lessons from this experience are highlighted in Box 1. The US example also generated interest in similar policy changes in other countries, leading eventually to new policy approaches and a change in thinking elsewhere regarding the appropriate scope of government intervention in this sector (Stanbury, 1989; Anderson et al 1998).

\section{Box 1: Lessons from the US experience with airline deregulation: the viability and benefits of competition}

Some of the specific lessons to emerge from analyses of the effects of deregulation in the US may be summarized as follows:

- A key benefit of deregulation was to promote new entry into particular markets, by both existing and start-up carriers. From 1978 to 2003, 129 new carriers entered the industry (Jordan, 2005);

- Enhanced freedom of entry and competition resulted in substantial improvements in performance, including an average 30-33 per cent reduction in fares for consumers in real, inflation-adjusted terms (Winston, 1998; Kahn, 2002). Significant productivity gains were also achieved, in part through new competitive strategies and operational adjustments made possible by the enhanced freedom of operations that deregulation provided (Borenstein, 1992; Kahn, 2002);

- Although many individual carriers (both large and small) have come and gone, deregulation has not led to significant reductions in service for small towns and rural communities. On the contrary, the number of scheduled departures available to such towns and communities has increased by 35-40 per cent (Kahn 2002);

- Deregulation has increased the need for effective application of competition (antitrust) law in the airline sector, particularly with respect to mergers and strategic alliances. In a deregulated environment, mergers and alliances are a key means by which carriers can (potentially) preserve or enhance their market power. In a number of actual cases where airline mergers were allowed to proceed, concentration in city-pair markets increased and consumer welfare was diminished (Morrison and Winston, 1990; Borenstein, 1992; Jordan, 1988; Kahn, 2002);

- A related finding with implications for economic policies in this and other sectors is that the mere elimination of regulatory barriers to entry has not generally proven sufficient to prevent higher-thancompetitive pricing in the airline sector - actual competition in city-pair markets is required (Joskow et al., 1994; Morrison and Winston, 1990). This has called into question the so-called "contestability hypothesis" which implied that the mere threat of entry would often suffice;

- Contrary to fears expressed at the time, there is no evidence that deregulation resulted in lower safety levels for consumers (Jordan, 1997; Kahn, 2002). In fact, air travel is now demonstrably safer than in the pre-deregulation period. While this may be due in part to extraneous developments (e.g., improved technology), it at least makes clear that deregulation did not usher in an era of heightened risks for passengers. In making sense of this picture, it is important to note that deregulation in the US did not involve any relaxation of legislated safety controls administered by the Department of Transportation and other authorities; rather, it focused on the economic aspects of regulation (i.e., the above-mentioned controls on entry, exit and pricing). 
In continental Europe, deregulation started later than in the US and followed a slower pace. The 1992 Single Market initiative played a key role in the implementation of greater freedom of entry and pricing. Subsequently, various regulations issued by the European Council, reinforced by relevant enforcement actions and policy advocacy by the EC Commission, have further promoted freedom of pricing and operational flexibility across the Community (Button, 1990; Goldstein, 2001). Since then extensive competition from low cost carriers has triggered significant fare reductions for consumers in many intra-EC city-pair markets for passenger air service. Most recently, intra-EC deregulation has been complemented by a major external market-opening initiative by the EC Commission (for further discussion, see Section 6, below).

In Africa, efforts to promote investment in necessary infrastructure and achieve more efficient service within the region have achieved mixed results. According to Goldstein (2001), the continent has historically trailed behind regulatory reforms implemented in the civil aviation sector in the rest of the world, both among the OECD economies and in Asia and Latin America. This has impeded efforts to increase tourism flows, attract FDI and enhance export performance. He suggests that a specific deficiency has been a lack of attention to competition promotion and enforcement, a choice that has put at risk the potential welfare gains from privatization and related changes in ownership and governance structures. In some cases, particularly in SubSaharan Africa, the safety of air transport services has also been a concern. Reflecting this, improving airline safety while promoting efficient international linkages has been a focus of various US initiatives in the region (Goldstein, 2001).

The foregoing brief discussion of approaches to regulation, deregulation and regulatory cooperation in the domestic air transport sector highlights a number of lessons. First, the record indicates clearly that the elimination of restrictions on entry, exit and pricing in domestic air transport in many countries has been associated with substantial improvements in performance. This may have implications for the remaining regulatory barriers to market access in international aviation markets. Second, unless particular attention is given to the maintenance of competition through the enforcement of relevant laws and other measures, the potential benefits of deregulation may be attenuated. This important issue is further elaborated in subsequent Sections of this essay. Third, it is important that necessary safety-related and other technical regulations be separated from economic regulation of entry and pricing. Liberalization with regard to the latter need not and should not imply compromises with respect to the former. Fourth, regional integration and cooperation can be important tools for promoting procompetitive changes in regulatory structures, particularly in the context of smaller, developing countries. Finally, as with respect to all aspects of governance, credible institutions are essential.

\section{(ii) Privatization}

One observer of international air transport policy has noted that owning a national flag carrier was for many years akin to having membership in the United Nations. This remark highlights the prevailing public policy view towards airlines. A similar view often holds on airports. Thus, international air transport was dominated in the past by publicly owned carriers transporting freight and passengers to and from publicly owned airports.

Arguably the two biggest catalysts for change occurred during the 1980s. These were the process of deregulation in the US domestic market (see Box 1) and strong economic growth in the Asia Pacific region. The first of these factors led to a re-thinking of how national governments should regulate the air transport industry and the second ensured that any assessment of the air transport industry had to accommodate the phenomenal growth in international trade and income, which was being driven largely by the Asia Pacific region. One of the first airlines to be privatized during this period was British Airways (1982). This was followed by Japan Air Lines that same year and a number of other airlines in developed countries such as Australia (Qantas), Canada (Air Canada), Germany (Lufthansa) and France (Air France). Developing countries such as Singapore and Malaysia privatized their airlines in 1985 (Bowen and Leinbach, 1996).

The trend towards privatization, while strong, is not universal, nor has it been an easy policy to implement for some countries. The Government of India, for example, stated its intention to privatize its national carriers 
Indian Airlines and Air India. However, more than five years later, it is still trying to do so. ${ }^{17}$ Also, Air Jamaica has recently returned to government control after a nine year experience with privatization. ${ }^{18}$

\section{(iii) Foreign ownership}

Against the backdrop of increasing growth in world traffic and financial pressures, a key development in the past decade has been to ease restrictions on the foreign ownership of international carriers. Therefore, a key strategy to increase competitiveness is not only to privatize, but also to allow foreign entry. Table 5 provides a snapshot of foreign ownership regulations applied by different countries. It shows that the practice is not uniform, with different countries applying different limits. Certainly, complete liberalization of foreign ownership regulations has not occurred; on the contrary, such regulations remain a barrier to a more competitive international airline industry.

It should also be noted that the experience of different countries with foreign owernship regulation has been mixed. British Airways purchased an equity stake in Qantas (Australia), once the Australian government permitted foreign entry, but has since sold this stake. In Latin America, LAN, which is based in Chile, has affiliate airlines in the Dominican Republic, Ecuador and Peru.

Liberalizing foreign investment regulations is perhaps one of the most contentious issues in the governance of the international air transport industry. The current system of regulation, which will be discussed in more detail later in Section 6, allows many national governments to grant market access only to designated 'national' airlines. Many people argue that foreign investment liberalization acts as an anchor to growth in the industry. Furthermore, the restriction of equity alliances amongst air carriers can create an incentive to engage in nonprice competition in the form of non-equity alliances.

\section{(iv)}

\section{State aid}

There is an on-going debate about the role of state aid in the international air transport industry. This debate cuts across many different aspects of the industry, such as aircraft manufacturing, competition amongst airports and assisting the financial survival of airlines. One of the most prominent issues in this debate in the international trade context is the role played by governments in the manufacture of aircraft. ${ }^{19}$ Brazil and Canada are two of the most important exporters of short-range commuter aircraft, with approximately up to 150 seats. In 2002, Canada successfully argued that Brazil's use of government funds to subsidize exports of Brazilian aircraft were inconsistent with its commitments under the Agreement on Subsidies and Countervailing Measures. ${ }^{20}$ In 2002, Brazilian won a similar challenge under the same agreement against the Canadian government's use of its funds to subsidize exports of Canadian aircraft. ${ }^{21}$

The European Communities (EC) and the United States are also in the midst of a dispute with respect to the production of large civil aircraft. ${ }^{22}$ In 1992, the two parties - the only producers of such aircraft - signed an agreement to limit the use of government funds in their respective large industries. In January 2005, the two parties have reached an intermediary agreement on steps towards resolving their disagreements (Box 2). ${ }^{23}$

17 "More Passages to India", Economist, 2 December, 2004. www.economist.com. "India moves to modernise its market", Airline Business, February 2005.

18 "Air Jamaica returns to state control", Airline Business, February 2005.

19 Gary Becker, "Airline bailout sets a bad precedent", Newsweek, 26 November, 2001, p. 28. Also, "Bush signs airline bailout package", www.cnn.com, 23 November, 2001.

20 Full details can be found in WTO document WT/DS46.

21 Full details can be found in WTO document WT/DS222.

22 There is no precise definition of large aircraft. In most cases, references are made to aircraft with more than 100 seats that are designed to travel between large hubs. The aircraft models at the centre of the Brazil-Canada dispute are designed to travel between smaller ports that are a shorter distance apart with a smaller passenger and freight loads.

23 http://www.ustr.gov/Document_Library/Press_Releases/2005/January/Statement_of_U.S._Trade_Representative_Robert_ B._Zoellick_Regarding_US-EU_Agreement_on_Terms_for_Negotiation_to_End_Subsidies.html 
Table 5

Foreign ownership regulations in air transport, 2002

\begin{tabular}{|c|c|c|}
\hline Country & Limit & Notes \\
\hline Argentina & $49 \%$ & $\begin{array}{l}\text { In the case of Aerolineas Argentinas, } 85 \% \text { shareholding by Interinvest (Spain, } \\
\text { US etc.) was allowed. }\end{array}$ \\
\hline Australia & $49 \%$ & $\begin{array}{l}\text { There are no foreign ownership restrictions for purely domestic operators. For } \\
\text { Australian international operators, foreign shareholder participation is limited } \\
\text { to } 49 \% \text { "unless this is contrary to the national interest". Qantas is regulated } \\
\text { under the provisions of the Qantas Sale Act of } 1992 \text {. Aggregate foreign } \\
\text { ownership is limited to } 49 \% \text { with up to } 35 \% \text { allowed to be held by foreign } \\
\text { airlines, with a maximum of } 25 \% \text { for any single foreign airline. }\end{array}$ \\
\hline Brazil & $49.50 \%$ & Since 1997 (previously 20\%). \\
\hline Canada & $25 \%$ (voting) & Exceptions may be granted by the competent regulatory authorities. \\
\hline Chile & & No restriction but airline must have its principal place of business in Chile. \\
\hline China & $35 \%(25 \%$ voting $)$ & Since May 1994 , intended to change to $49 \%$. \\
\hline Czech Republic & $49 \%$ & At least $51 \%$ shares and voting are owned and controlled by nationals. \\
\hline EU Member States (15) & less than $50 \%$ & $\begin{array}{l}\text { Bound by EU Regulation } 2407 / 92 \text { (community carrier) for investors from non-EU } \\
\text { Member States, but no restriction on investments from EU Member States. }\end{array}$ \\
\hline Japan & $33.33 \%$ & $\begin{array}{l}\text { Japanese carriers must be owned, controlled and managed by more than two- } \\
\text { thirds by Japanese nationals. }\end{array}$ \\
\hline India & $40 \%$ & $\begin{array}{l}40 \% \text { in private domestic airlines, but investments from foreign airlines or } \\
\text { airport investors are not allowed since April } 1997 .\end{array}$ \\
\hline Indonesia & & Initially 49\%, abolished by a Presidential decree in 2000. \\
\hline Kenya & $49 \%$ & \\
\hline Korea, Rep. of & less than $50 \%$ & $\begin{array}{l}\text { Raised from } 20 \% \text { to } 49.99 \% \text { on } 12 \text { February } 1998 \text {, provided that effective } \\
\text { control remains with Korean nationals. }\end{array}$ \\
\hline Malaysia & $45 \%$ & Applied to Malaysia Airlines, changed from 30\% to 45\% in July 2000. \\
\hline Mexico & $25 \%$ (voting) & $\begin{array}{l}\text { Since } 1994 \text { allows over } 25 \% \text { limit if investment through firms where foreign } \\
\text { investment is less than } 50 \% \text { of voting stock. }\end{array}$ \\
\hline New Zealand & $49 \%$ & $\begin{array}{l}\text { Since } 1996,25 \% \text { for single foreign airline, and } 35 \% \text { for total foreign airlines. } \\
\text { At least } 50 \% \text { ownership and effective board control by Australian and/or New } \\
\text { Zealand nationals (SAM airline). }\end{array}$ \\
\hline Peru & $70 \%$ & Since 1997. \\
\hline Philippines & $40 \%$ & $\begin{array}{l}\text { Airlines are considered to be public utilities. All executive and managing officers } \\
\text { must be nationals. }\end{array}$ \\
\hline Poland & & $\begin{array}{l}\text { Air Law of } 1962 \text { (Article 65a) requires authorization by the Minister of } \\
\text { Transport and Maritime Economy. }\end{array}$ \\
\hline Russian Federation & & $\begin{array}{l}\text { In } 1997 \text { the Russian Government introduced rules which would bar foreign } \\
\text { majority ownership in joint venture airlines. }\end{array}$ \\
\hline Singapore & & There are no formal restrictions on ownership of Singapore companies. \\
\hline Switzerland & $40 \%$ & $\begin{array}{l}\text { After joining the European Common Aviation Area (ECAA), same rules as for } \\
\text { EU Member States. }\end{array}$ \\
\hline Taipei, Chinese & $33 \%$ & Domestic airlines, 50\% apply to air-cargo since 1997. \\
\hline Turkey & $49 \%$ & $\begin{array}{l}\text { Turkish airlines must be incorporated in Turkey and majority-owned, controlled } \\
\text { and managed by Turkish nationals. }\end{array}$ \\
\hline Thailand & $49 \%$ & $\begin{array}{l}\text { Requirement of state ownership in Thai International reduced from } 70 \% \text { to } \\
51 \% \text {. Angel Air's foreign equity limitation was changed from } 15 \% \text { to } 30 \% \text {. }\end{array}$ \\
\hline United States & $49 \%$ (25\% voting) & $\begin{array}{l}\text { Two-thirds of the board of directors must be nationals and effective control } \\
\text { must be national. Could be subject to control test. }\end{array}$ \\
\hline
\end{tabular}

Sources: ICAO, IATA.

Not surprisingly, airports with excess capacity will compete to obtain business. If the competition is intense, airports could resort to incentives that may be regarded as subsidies. This issue is illustrated in a recent case involving Charleroi airport near Brussels and Ryannair, a LCC based in Ireland. The European Commission ruled that the authorities of Charleroi airport, a public company, offered financial incentives to Ryannair that were exclusive. Accordingly, Ryannair had to pay back some of the funds. The result of the ruling is that the airport could still offer incentives, but had to do so in a non-discriminatory fashion. 


\section{Box 2: US-EU Agreement on terms for negotiation to end subsidies for large civil aircraft}

1. The objective is to secure a comprehensive agreement to end subsidies to large civil aircraft producers in a way that establishes fair market competition for all development and production of LCA in the European Union and the United States.

2. At present, the companies concerned in the EU are Airbus and its principal shareholders, and in the US, Boeing.

3. The Agreement will be negotiated within three months.

4. (a) The Agreement will be negotiated between and apply to the United States and the European Union.

(b) These parties will subsequently work together to broaden the agreement to include as parties other countries with civil aircraft industries, or countries with risk-sharing roles relevant to the objective of the Agreement.

5. (a) During the negotiations the parties will not request establishment of WTO panels relating to the pending disputes.

(b) During the negotiations, within the time frame foreseen in paragraph 3 above, the parties will make no new government support commitments for LCA development or production.

6. The parties will use the definition of subsidies in the ASCM. The parties will agree an illustrative list of subsidies to be covered by the Agreement which elaborates the ASCM definition. They will use this list to reach agreement on which form of subsidy should be prohibited, actionable or permitted.

7. The Agreement will be enforced through transparency and strong dispute settlement procedures.

8. In negotiating the Agreement the parties will establish agreed terms and conditions under which either may withdraw at a future date. On the one year anniversary of the Agreement, the parties will review its operation, including whether progress on international participation in it is sufficient to prevent circumvention of its objectives and to justify its continuation.

Source: European Commission and Office of the United States Representative.

The ruling has broader implications in the context of the development of new city-pairs and airports that are publicly owned. One consequence of the development of LCC, in addition to stimulating growth and lowering prices, has been the creation of city-pairs which contribute to regional development. A concern here is that if regional airports are limited in how they compete against each other, especially through limits on fiscal incentives, the LCC model may not survive.

A third area of state-aid that has received attention is direct contributions to airlines to ensure their financial survival. The airline industry experiences cyclical fluctuations in its profitability. In addition, events such as 11 September, 2001 and SARs can exacerbate an already poor financial situation. The extent to which governments should be permitted to provide financial assistance to some of its airlines has caused considerable debate. A recent case is the provision by the United States of $\$ 15$ billion available to its airlines two weeks after 11 September, 2001 events. ${ }^{24}$ A similar issue has arisen in the European Community in the context of the Italian government seeking ways to ensure the survival of Alitalia. A number of measures that it has contemplated have been controversial with a number of other European governments.

24 Airline Transportation Safety and System Stabilization Act, Pub. L. No. 47-102, I, § 103(b)(2)(A), http://frwebgate.access gpo.gov/cgi-bin/getdoc.cgi?dbname=107_cong_bills\&docid=f:h2926enr.txt.pdf 
These three forms of state-aid - to aircraft manufacturing, airports and airlines in financial difficulty - will not disappear in the near future, nor will the controversy over their use. In the context of this essay, one of the more important aspects of this question is how far international cooperation will limit the impact of subsidization on international trade patterns.

\section{(v) Market access}

Market access in international air transport is defined by a number of variables, including the designation of carriers, the entry of these carriers on specific routes and the flexibility to establish capacity and prices on routes. As a starting point, the industry has defined eight different types of international air traffic, which it has called freedoms (Box 3). These range from the first freedom to overfly another country to the right to carry freight and passengers on domestic routes in a foreign country. The freedoms have evolved from the basic sovereign right possessed by every country to regulate air traffic within its borders. Exercise of this right means that national governments have the right to decide which carriers have access to the various freedoms and in which manner.

The granting of the first two freedoms has typically not been controversial. ${ }^{25}$ Similarly, granting the third and fourth freedoms has not been controversial in a bilateral context, although the terms and conditions of access have traditionally been quite restrictive. The failure of the multilateral approach in 1944 resulted in mercantilist market access bargaining among nations. This means that states typically enter into negotiations with the intention of securing significant market access gains, while at the same time minimizing their concessions. The end result is an agreement that results in little liberalization. This appears to have been the case for the first bilateral agreement, Bermuda I, (Loy, 1996).

The Bermuda I Agreement was the template for the international air transport industry until 1978, when the US and the UK signed another Agreement (Bermuda II). This also was characterized by a substantially high level of intervention over capacity, fares, frequency, routes and type of plane and therefore limited market access. Granting third and fourth freedoms with only one flight per day is very different from granting the same freedoms without any restrictions on how and where the service is delivered.

Section 6 reviews the various approaches different governments have taken to liberalize market access. These approaches have remained predominantly bilateral, but become more liberal with respect to pricing, capacity and routes. One area where they have not been ambitious is in the national designation of the carrier allowed to take advantage of the liberal provisions. This issue is linked directly to foreign ownership. A bilateral agreement that restricts the carriers which are allowed to take advantage of additional liberalization may not achieve the desired objectives.

25 The manner in which the Russian Federation charges for First Freedom access has been the matter extensive debate (WTO S/C/W/163/Add.3, p. 9). 


\section{Box 3: Air freedom rights in air services agreements}

\section{FIRST FREEDOM}

To overfly one country en-route to another

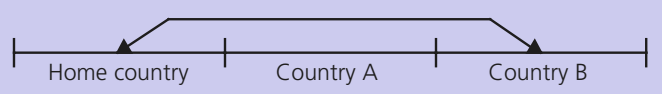

\section{SECOND FREEDOM}

To make a technical stop in another country

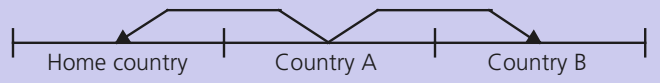

\section{THIRD FREEDOM}

To carry freight and passengers from the home country to another country

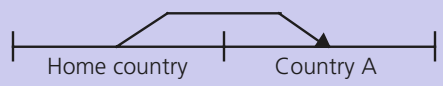

\section{FOURTH FREEDOM}

To carry freight and passengers to the home country from another country

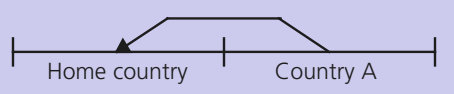

\section{FIFTH FREEDOM}

To carry freight and passengers between two countries by an airline of a third country on route with origin / destination in its home country

\section{SIXTH FREEDOM}

To carry freight and passengers between two countries by an airline of a third country on two routes connecting in its home country

\section{SEVENTH FREEDOM}

To carry freight and passengers betweeen two countries by an airline of a third country on a route with no connection with its home country

\section{EIGHTH FREEDOM OR CABOTAGE}

To carry freight and passengers within a country by an airline of another country on a route with origin / destination in its home country

\section{TRUE DOMESTIC}

To carry freight and passengers within a foreign country with no connection with the home country
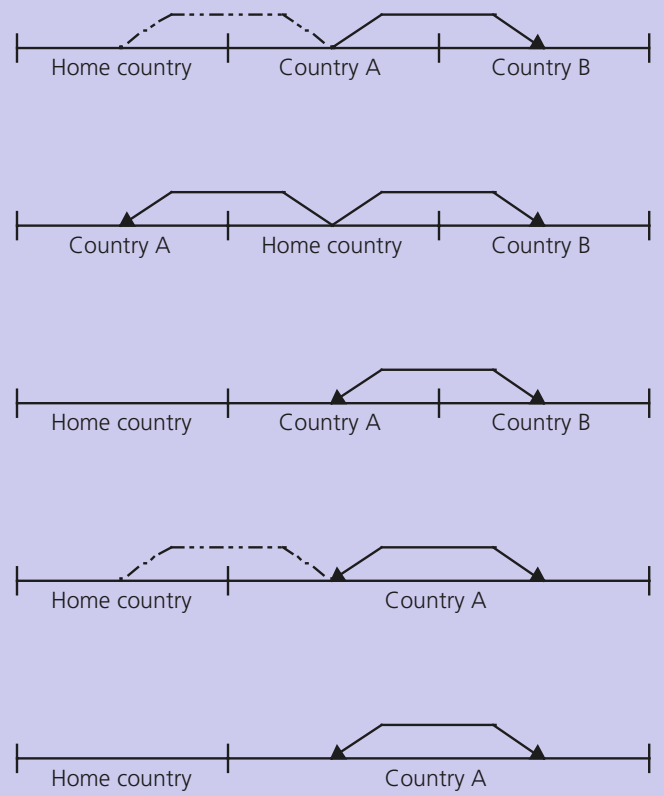

\section{(e) Summary comments}

Each of the four broad issues identified above impact the pattern, volume and value of trade in international air transport. Together, they define the operating environment within which passenger and cargo carriers must operate. A clear picture of deregulation and liberalization in the domestic and international markets emerges, despite the fact that most national governments have not allowed full foreign ownership of their airlines. This trend and its positive consequences for prices and efficiency has been well documented in a number of studies that have examined the policy structure governing international air transport.

Gonenc and Nicoletti $(2000,2001)$ and Doove et al. (2001) are amongst the most recent studies to show that limitations on market access for international air carriers raises prices. ${ }^{26}$ The Doove et al. (2001) study, for example, examined the effects of restrictions in 35 economies and found that the price increase for domestic fares arising from these restrictions ranged from 3 to 22 per cent. Indeed, they show that the more restrictive the regime, the higher price premium on air fares. For example, the US has the most liberal regime and was found to have the lowest premiums. These findings support the conclusions of Forsyth's (1998) general review

26 See also Dresner and Tretheway (1992), which contains similar conclusions. 
of the issues. Oum and Yu $(1995,1998)$, show that the more liberal the regulatory environment, the more efficient will be the airline. Gonenc and Nicoletti (2001) come to similar conclusions after analysing business and discount fares in 100 city-pairs.

Air cargo is another aspect of air transport that is affected by various forms of regulation. Recent research has shown that the trend towards more liberalized agreements can have an impact on freight costs and thereby on the costs of conducting international trade transactions. For example, a reduction in transport costs of 8 per cent is estimated to increase trade by 10 per cent (Micco and Serebrisky, 2004).

\section{COMPETING IN THE AIR TRANSPORT INDUSTRY}

The previous Section showed that the regulatory and external environment within which air carriers are operating is changing rapidly. This Section examines some of the mechanisms by which airlines are responding to this changed environment.

\section{(a) Networks}

A number of changes in how services are delivered in the air transport industry have occurred in the past 30-40 years. In the pre-jet era, international air transport services were offered in a network that could be described as linear, or point to point. Intermediate points were used for refuelling stops. Once the technical capability of aircraft and choice of aircraft expanded, intermediate stops were by-passed to shorten the travelling time between two points, and where feasible, separate routes were established between the intermediate stops and the final stops. As demand for air transport services grew larger, cities started to establish their airports as hubs and develop feeder services into their international airports. The delivery of transport services has now reached the stage where a final destination point can be serviced through a number of hubs that were not on the original linear transportation network.

The concept of hubs and spokes is not new to international air transport. As indicated before, global air traffic can be divided into three main regions - East Asia, Europe and North America. Initially, each region had one or two major hubs, but as demand for air travel grew and the cost of providing international services declined, more hubs were established. As a result, places such as Hong Kong, China and Singapore, which do not have a domestic base, survive on the basis of being hubs for traffic to Europe or the South Pacific. ${ }^{27}$ In this context the third and fourth freedoms that they have negotiated in their bilateral agreements are important for the profitability of their airlines. It also means that these two economies are in a strong position to demand fifth freedoms.

An important aspect of competing in the presence of fixed costs is the decreasing returns that come from increasing output, or from agglomerating different activities. The experience of the United States' domestic market, which is one of the largest markets for air travel in the world, shows that carriers that compete solely on the basis of hubs rely on their 'spoke' markets to feed traffic into the hubs. A consequence of this strategy, is that if the different spokes are not connected by an airline, then that airline could result in competitors entering to service this gap. A similar situation could arise in international markets.

The conditions of establishment are quite different in domestic and international air transport. This is because in domestic markets countries can simply exercise their sovereign right to control air traffic over their air space and between points that are origins or destinations within their territory. In international markets, networks can only be established through cooperation with other governments. This means that entry in international

27 Much is written about the emergence of the hub and spoke model in the domestic market for air transport in the United States. When the market was heavily regulated many of the major cities were serviced. However, these services were typically very expensive and service was infrequent. After deregulation, the hub and spoke model emerged as the basis on which the major carriers competed. While there was some competition between the various spokes, this was difficult to maintain due to the possible conflict of servicing both the spokes and the hubs. 
markets faces considerably higher barriers than in domestic markets, where in most countries domestic airlines can enter and exit relatively freely. As discussed later, these barriers will affect the type of international network that an airline may wish to establish. A network with spokes that are in different countries is more difficult to establish than an international hub with domestic spokes.

\section{(b) Price competition}

The emergence in Western Europe and the United States of the low cost carrier (LCC) concept has had a profound impact on how airlines compete. The traditional model of a full-service airline that delivers a range of services has been under threat for the past two decades by a new business model, which emphasises lower price tickets, but correspondingly lower levels of services.

The basic hypothesis driving the LCC model is that passengers are purchasing travel between two points, as opposed to a bundle of services in addition to the travel. By offering cheaper fares to passengers and full information about the reduction in services, a number of airlines such as Virgin Blue in Australia, Southwest in the United States and Easyjet and Ryanair in Europe have become quite successful.

As suggested by their name, LCCs obtain their advantage by lowering their costs. This can be achieved a number of ways, especially if an airline is new. Older, more established international airlines that are referred to as national airlines, or legacy airlines, have cost structures that make them less nimble in responding to competitive pressures. ${ }^{28}$ Of these, labour costs, which account for up to 40 per cent of total costs, appear to be one of the most significant. Another cost advantage is in the efficient use of aircraft. Long-haul flights require consolidation of routes in order to make the provision of the service profitable. LCCs, so far, have focused predominantly on short-haul flights of less than two hours in duration. By selecting only one type of route to service, LCC can also reduce costs by using a single aircraft type. This not only lowers maintenance costs, due to the uniformity of service, it also leads to a reduction in the time on the ground to service and unload an aircraft (Gillen and Lall, 2004).

One of the most visible and tangible means by which LCCs have been able to compete is by using direct customer contact to sell their services. The availability of secure purchasing on the internet has provided a number of novel ways by which potential customers can examine their travel options. By cutting out travel agents, LCCs do not have to pay commission and in many cases, an electronic ticket is issued, which means the airline can save on administration charges. The use of the internet to book airline tickets is not confined to LCCs. Legacy carriers and now also some travel agents are making extensive use of the internet. The end result is that the effect of the internet on air travel is to make the pricing of air tickets more transparent, since customers can easily compare price quotes, thereby ensuring that prices remain a key strategic competition tool for airlines.

The concept of an international LCC, if the EU is counted as one market, is still in its infancy, but appears to be showing strong growth, especially in East Asia (Hooper, 2004). This is not altogether surprising given the demand for air travel in that region and the number of countries involved. Recent entrants into the South-East Asian market using the LCC model include airlines based in Indonesia, Malaysia, Singapore and Thailand. The expansion of the European Community to 25 countries has also resulted in a number of LCC entrants, based in the new states, attempting to take advantage of the single aviation market. ${ }^{29}$

China and India are two of the largest and fastest growing markets for international air travel in developing countries. As of yet, neither has an LCC, although media reports indicate that a number of enterprises are considering establishing an LCC in the next two to three years.

28 The evolution, impact and future of LCC airlines is examined in "Low-cost airlines: Turbulent Skies", Economist, 8 July, 2004.

29 "Spreading Wings: Yet more low cost startups", Economist, 13 May 2004. 


\section{(c) Non-price competition}

While the deregulation of the industry has promoted healthy price competition, the existence of a number of regulatory entry barriers has triggered new forms of non-price competition among airlines on international routes. Of these the most common is the formation of non-equity alliances. An argument can be made that such alliances are simply pro-competitive responses to entry barriers against foreign airlines. In the absence of outright establishment, or a controlling share of another international airline, alliances that involve codesharing and the coordination of schedules across networks can provide a number of benefits.

From the carriers' perspective, some of the principal reasons for codesharing are:

- to achieve a better display position in computer reservation systems in cases where a codeshare is treated as an on-line service with a higher priority in listing than interline service;

- in the context of an increasingly competitive environment, to form some kind of cooperative links with other carriers to maintain, protect and improve market positions;

- to achieve better presence on routes carriers do not fly, as an inexpensive marketing tool;

- to enable joint operation carriers to operate a viable service where traffic volumes do not justify individual operations, and to obtain feeder traffic;

- to foster competitiveness by drawing traffic within the orbit of codesharing partners; and

- to obtain increased market access to points hitherto restricted by capacity provisions in bilateral air services agreements.

From the passengers' perspective, potential advantages are:

- the convenience of coordinated schedules, allowing for improved connections;

- possible shorter elapsed journey time;

- shared terminals between partner carriers facilitates transfer;

- the possibility of lower fares or greater choice of special fares;

- single carrier supervision of the through journey; and

- common frequent flyer programmes.

Table 6 illustrates the current landscape of alliances across international carriers. In 2002 there were five major alliances, but now after consolidation in the industry, only three exist: Oneworld, Star Alliance and SkyTeam. An important feature of these alliances is the inclusion of a major airline from one of the three important regions for air traffic. This way, each airline can claim to have a hub in the region that can be used to connect with hubs in other regions. For example, for the Oneworld alliance, American Airlines uses its hubs in the US for the alliance, as does British Airways for Europe. In East Asia and the Southern Pacific, the hubs are Hong Kong, China (Cathay Pacific) and Sydney (Qantas).

\section{(d) Implications for international trade}

The picture that has been painted by the previous Sections is of a dynamic air transport industry. The industry has shown resilience, responding positively to the many challenges it has faced. A pro-competitive environment has emerged from the systematic move towards privatization and deregulation. The implications for international trade are clear - as tariffs and restrictions to international trade in goods and services are reduced, there will be a greater demand for air transport.

While the growth prospects for air transport look positive, what is not predictable is the pattern of trade in international air transport. Two, perhaps competing, views exist as to what the landscape of air traffic will look like in the medium term. One is the view that demand will be accommodated by a few very large international 
Table 6

Alliances between air carriers

\begin{tabular}{|c|c|c|c|}
\hline \multicolumn{4}{|c|}{ SKYTEAM } \\
\hline Members & Passengers (Thousands) & RPKS $^{1}$ (Scheduled Millions) & ASKS $^{2}$ (Scheduled Millions) \\
\hline Aeromexico & 8835 & 12982 & 19965 \\
\hline Air France & 44405 & 99863 & 131719 \\
\hline Alitalia & 22259 & 28170 & 39023 \\
\hline Continental & 39856 & 94783 & 125593 \\
\hline CSA & 3344 & 4784 & 6622 \\
\hline Delta & 84124 & 143478 & 192975 \\
\hline KLM & 18741 & 56555 & 71366 \\
\hline Korean Air & 21270 & 39936 & 58284 \\
\hline Northwest & 52788 & 110199 & 142573 \\
\hline Total & 295622 & 590750 & 788120 \\
\hline \multicolumn{4}{|c|}{ STAR ALLIANCE } \\
\hline Members & Passengers (Thousands) & RPKS $^{1}$ (Scheduled Millions) & ASKS $^{2}$ (Scheduled Millions) \\
\hline Air Canada & 19857 & 59018 & 79630 \\
\hline Air New Zealand & 10123 & 22689 & 31041 \\
\hline ANA & 43388 & 52077 & 81297 \\
\hline Asiana & 11703 & 16156 & 23781 \\
\hline Austrian Airlines & 6895 & 14537 & 20387 \\
\hline bmi & 9113 & 6514 & 9972 \\
\hline Blue1 & 628 & 411 & 920 \\
\hline LOT & 3252 & 5434 & 7592 \\
\hline Lufthansa & 44477 & 96617 & 124166 \\
\hline SAS & 26537 & 26733 & 39480 \\
\hline Singapore Airlines & 13124 & 63816 & 88580 \\
\hline Spanair & 5831 & 5143 & 7979 \\
\hline TAP Air Portugal & 5841 & 12012 & 16837 \\
\hline Thai & 16623 & 44773 & 63952 \\
\hline United Airlines & 66526 & 167136 & 217798 \\
\hline US Airways & 41251 & 60736 & 82870 \\
\hline Varig & 11329 & 26081 & 36605 \\
\hline Total & 336498 & 679883 & 932887 \\
\hline \multicolumn{4}{|c|}{ ONEWORLD } \\
\hline Members & Passengers (Thousands) & RPKS $^{1}$ (Scheduled Millions) & ASKS $^{2}$ (Scheduled Millions) \\
\hline Aer Lingus & 6596 & 9963 & 12271 \\
\hline American & 88798 & 193135 & 265199 \\
\hline British Airways & 34815 & 100426 & 137483 \\
\hline Cathay Pacific & 9991 & 42727 & 59224 \\
\hline Finnair & 5556 & 8641 & 13792 \\
\hline Iberia & 25087 & 41956 & 55930 \\
\hline LAN & 5509 & 13255 & 19013 \\
\hline Qantas & 23520 & 68923 & 89064 \\
\hline Total & 199872 & 479026 & 651976 \\
\hline
\end{tabular}

1 RPKS - Revenue passenger kilometers.

2 ASKS - Available seat kilometers.

Note: All data sourced from IATA WATS 2004; figures relate to 2003. TAP Air Portugal joins the Star Alliance in March 2005.

Source: IATA.

hubs, which will be serviced by a number of smaller ports (spokes). If this view prevails, then the smaller ports, which would be predominantly lower income developing countries, would look to gaining access to the hubs in order to export their goods and services.

Another view is that while the hub and spoke system will not disappear, increased demand will be accommodated through point-to-point service. In this view, the traffic volumes between hubs will be substituted by traffic volume that "closes the spokes". 
These differences in predictions are best embodied in the commercial ambitions of the two largest aircraft manufacturers: Airbus and Boeing. Airbus subscribes to the view that hub traffic necessitates larger aircrafts as these hubs face capacity constraints. Boeing, on the other hand, predicts that medium size, long range aircraft that will be needed so that points can be serviced regardless of distance.

In reality, there is no reason why both views cannot co-exist. As indicated before, air traffic is heavily concentrated within and between three regions. It will continue to grow that way. However, one aspect of this growth is the extent to which smaller, lesser developed countries will be marginalized from the infrastructure that they require to integrate into the world trading system. Two prime examples of the difficulties that these countries face relate to demand for tourism and fresh fruit and vegetable exports..$^{30}$ The tourism industry is very competitive and many small economies are highly dependent on air traffic to sell their tourism services. A hub and spoke system that increases the time and number of connections to potential customers could prove detrimental to their best efforts. Similar difficulties and problems arise in the case of time-sensitive exports such as fresh fish, flowers, fruits and vegetables. Many countries such as Fiji, Kenya and Zimbabwe rely on exporting such products to markets that are a considerable distance away, such as Europe in the case of African countries and Australia, Japan and the United States in the case of the South Pacific countries. For these countries, a point to point system would serve their interests better, but only if it is cost competitive for them.

A more efficient air transport system would promote development in Africa by facilitating trade, attracting investment, encouraging tourism and boosting cultural links, both within Africa, and between Africa and other regions of the world (Goldstein, 2001). Currently, African consumers enjoy a reasonable degree of choice (and therefore competition) on major Africa-Europe routes and within particular sub-regions of the continent, while service between major destinations in different parts of Africa is much less developed (ATAG, 2003).

Expanding service options in developing countries is likely to require a complex mix of interdependent policy initiatives, including further privatization, liberalization of market access at least within the region and eventually multilaterally, infrastructure investment, and competition advocacy. These reforms, in turn, are likely to require enhanced intergovernmental cooperation through appropriate regional and multilateral bodies. Strengthened product market competition (and hence improved efficiency) would also enhance the attractiveness of developing country carriers as possible partners in international alliances - generating further benefits for their service suppliers and consumers.

\section{THE ROLES OF COMPETITION LAW AND RELEVANT ENFORCEMENT AUTHORITIES}

The state of competition in the international air transport sector is a function of many variables, some of which have already been described in previous Sections of this essay. These include changing technology and demand conditions, the availability of necessary infrastructure and (very much) the conditions governing access to markets. As described above, for many years, the degree of competition in the international air transport sector has been limited by constraints on entry and (in some cases) pricing that are embodied in bilateral air service agreements. These, in turn, derive from the "piecemeal bilateralism" approach to international regulation of this sector that was adopted at the Chicago Convention in 1944 (see further discussion in Section 6, below). However, the state of competition in air transport also depends on firm strategies and behaviour and on public policies in relation to such strategies and behaviour (i.e., on the application of competition law and policy). The latter will be the subject of this Section.

More specifically, this Section of the essay will explore key conceptual, practical and empirical issues relating to the regulation of competition in the air transport sector. The primary focus will be on issues that have arisen

30 See Milner et al. (1998) for a review of how transport costs can act as an export tax in developing countries. 
regarding the maintenance of competition in international passenger air transport. ${ }^{31}$ The following issues will receive particular attention:

- the role of mergers, joint ventures and strategic alliances (including code-sharing arrangements) in the airline sector, their implications for competition and their treatment by competition authorities;

- the implications of antitrust immunity for the International Air Transport Association (IATA) and individual code-sharing arrangements for the assessment of arrangements in this area;

- issues concerning the possibility of inter-airline collusion, including through electronic tariff publishing and related channels;

- the treatment of predatory conduct (i.e., practices through which firms may seek to exclude potential rivals from markets) in the airline sector; and

- the contribution of competition advocacy - i.e., interventions by national competition authorities and other parties with related interests in national and international policy-making processes - in the international air transport sector.

The discussion will also touch briefly on issues concerning overlapping national jurisdiction regarding the maintenance of competition in the air transport sector, and the need for appropriate cooperation mechanisms in this regard.

The overall purpose of this Section of the paper is to provide a sense both of the various ways in which competition in the air transport sector can be adversely affected by anti-competitive practices, and of the ways in which such practices can be deterred/remedied by the application of sound competition rules. As will be seen, effective regulation of anti-competitive practices (in air transport as in other economic sectors) requires a discerning approach by relevant authorities which identifies structural amalgamations and conduct that are genuinely harmful to competition (and therefore to consumers) without coming in the way of efficient inter-lining arrangements, necessary re-structuring or pro-competitive pricing and other practices. The policies enforced by the competition authorities of leading jurisdictions with experience in this area seek to reflect this balance. The advocacy function of competition agencies in the context of the air transport sector will also be discussed. A key theme in this connection concerns the interaction of enforcement and advocacy concerns and, specifically, the role that competition agencies can play in promoting pro-competitive policy changes in this sector.

\section{(a) The role of mergers, joint ventures and strategic alliances in the airline industry}

The regulation of mergers, joint ventures and strategic alliances in the airline and other industries must be approached with caution: it is widely recognized that such arrangements can, in particular cases, be a legitimate tool for the re-allocation of resources and for achieving more efficient service. In fact, competition authorities typically find that most mergers and related arrangements in their respective economies are benign or even beneficial in terms of their impact on competition; it is only in a small minority of such cases that intervention by public authorities is warranted (Anderson and Khosla, 1995). Nonetheless, experience in the air transport sector indicates that both mergers and strategic alliances can create market power, reducing the benefits of market liberalization and raising fares/reducing service levels for consumers (Borenstein, 1990 and 1992; Morrison and Winston, 1989 and 1990; and Jordan, 1988 and 2002). The effects of particular mergers or similar arrangements depend, very much, on the circumstances prevailing in particular markets; accordingly, they are normally evaluated on a "rule of reason" or case-by-case basis. The challenge for relevant authorities is to identify and take appropriate action regarding the minority of such arrangements that pose a genuine threat to competition without coming in the way of the larger subset that is competitively benign or may result in better service for consumers (see, e.g., Bingaman, 1996; Nannes, 1999).

31 It should be noted that, in addition to the issues that are discussed below, the question of state aids (subsidies) for industry falls within the purview of competition authorities in some jurisdictions (notably the European Community). However, the main focus of this Section is on private anti-competitive practices rather than on state measures that limit competition. 
Merger analysis in the air transport sector (as in other industries) typically begins with delineation of the relevant product and geographic markets. The purpose of this exercise is to identify the range of products or services that consumers view as reasonable substitutes for the products or services of the merging firms (or firms participating in a joint venture, strategic alliance or similar arrangement). Typically, competition authorities find that relevant markets for the analysis of airline mergers and other arrangements are no larger than city-pair routes. ${ }^{32}$ Relevant markets may be narrower than city-pairs if, for example, not all flights on a given city-pair route are viewed as adequate substitutes for each other, perhaps because the departure or arrival times are inconvenient for specific business-related purposes (Bingaman, 1996). Another approach is to define the relevant product market as the provision of transportation services between particular city-pairs, recognizing that (particularly given the role of the Internet) tickets for such services can be sold over wide geographic areas (see, for related discussion, Jordan, 1975).

Once the relevant markets have been delineated, the implications of a proposed merger or strategic alliance for prices and the extent of consumer choice in the markets are assessed. ${ }^{33} \mathrm{~A}$ particular focus of concern for relevant authorities regarding the maintenance of competition in the passenger air transport sector relates to mergers that would eliminate competition from existing "hub carriers" - i.e., airlines that serve a large number of cities in a region through "hub and spoke" systems (McDonald, 2004). However, concerns can also arise with regard to mergers in which smaller carriers that provide a source of competition in niche markets are absorbed by competitors.

In addition to the number of competitors serving a particular city-pair route and their respective market shares, an important consideration in the analysis of any merger is the feasibility of entry into the market by new competitors. In the early years of airline deregulation, particularly in the United States, it was often assumed that barriers to entry in the airline industry were minimal in that key assets such as aircraft were readily transferable across markets. Indeed, the airline sector was widely cited as a leading example of a "contestable" market - i.e., a market in which entry is so easy that any effort to exercise market power by raising fares above competitive levels will be forestalled by the possibility of "hit and run" entry (see, e.g., Baumol et al. 1982 and Bailey, 1981). However, this view of the industry has since been largely rejected in both relevant economic literature (see, e.g., Borenstein, 1992) and in the work of competition law enforcement officials (see, e.g., Willig, 1991 and Nannes, 1999). This reflects a recognition that barriers to entry in this sector - arising, for example, from the impact of the hub and spoke system, a scarcity of take-off and landing slots or other airport infrastructure for some city-pairs and (in the view of some observers) reputation effects (i.e., a reputation for price-cutting in response to competitive entry) - are more extensive than previously thought (see Nannes, 1999, for a careful discussion).

Even in cases where intervention is deemed to be warranted, competition authorities typically are prepared to consider possible measures for redressing the anti-competitive impact of relevant arrangements that stop short of barring a merger or other transactions altogether. For example, concerns regarding the anti-competitive effects of a merger have, in a number of cases, been addressed through measures such as making available additional take-off and landing slots at airports to facilitate entry by new competitors. This is sometimes referred to as a "fix-it first" approach. An example of the use of this approach in the airline sector - namely in the Air France/KLM merger - is provided in Box 4.

\footnotetext{
32 As Bingaman points out, "A passenger who needs to travel from Washington to Kansas City will not go to Cleveland instead if fares to Kansas City increase."

33 See US Department of Justice and Federal Trade Commission (1997).
} 


\section{Box 4: A conditional approval of a merger with trans-national effects in the airline industry: the Air France/KLM case}

In September 2003, Air France and KLM announced plans to merge their ownership and coordinate their operations, while remaining nominally separate carriers. The merger would create the world's largest airline, as measured by revenue.

Because Air France and KLM were members of competing alliances (SkyTeam and Wings, respectively), the merger would also (potentially) have created the incentive and ability to coordinate the activities of all carriers belonging to these alliances. Therefore, in the US, it was analysed as a worldwide merger of alliances, requiring examination of the likely effects on hundreds of city pairs.

In negotiations by the parties with the European Commission, the two carriers reached agreement on a set of commitments to alleviate possible anti-competitive effects in both intra-Europe and beyond Europe markets. These included a surrender of 47 landing and takeoff slot pairs, a "frequency freeze" (agreement to refrain from increasing frequency on affected routes to give new entrants a fair chance to establish themselves) and assurances by the Dutch and French governments that they would give traffic rights to other carriers wishing to stop over in Amsterdam or Paris. Based in part on the remedies exacted by the EC Commission, the US Department of Justice did not seek to prohibit the merger.

Source: EC Commission (2004a) and McDonald (2004)

In addition to mergers, superior efficiency can sometimes be achieved through strategic alliances or codesharing arrangements. Such arrangements may comprise little more than one airline allowing another to sell seats on its planes on a route in which it cannot compete directly (essentially, an interlining arrangement). Alternatively, they can involve a much more comprehensive integration of marketing and operations including joint decisions on fares, capacity and scheduling.

The treatment of code-sharing arrangements under competition law involves the same principles as that of airline mergers. As Bingaman (1996) states:

"To antitrust law enforcement authorities, code-sharing agreements are simply forms of corporate integration that fall somewhere between outright merger and traditional arm's length interlining agreements. As with mergers and acquisitions, ...code-sharing has the potential to be significantly procompetitive - it can create new service, improve existing service, lower costs and increase efficiency, all to the benefit of the travelling public. By the same token, code-sharing can also be a mask for anticompetitive arrangements between actual or potential competitors to allocate markets, limit capacity, raise fares, or foreclose rivals from markets, all to the ultimate injury of consumers. The ability to distinguish the latter from the former is crucial for aviation policy-makers and antitrust enforcement authorities."

In circumstances where an alliance does not involve any tangible efficiencies or joint services that would not otherwise be provided its effects may be analogous to a cartel (i.e., a pure price-fixing or market-sharing arrangement), in which case it may be appropriate that it be prohibited outright. ${ }^{34}$

In sum, both mergers and related arrangements such as code-sharing or strategic alliances are normally evaluated by competition authorities on what is known as a case-by-case or "rule of reason" basis. Under this approach, arrangements are normally deemed acceptable to the extent that they provide enhanced efficiency or new services that would not otherwise be available to consumers. On the other hand, where such arrangements reduce or eliminate competition between carriers serving the same markets, the relevant authorities may require concessions to alleviate the anti-competitive effects or even seek to prohibit the arrangement outright.

34 On the distinction between "naked" price-fixing cartels and potentially benign cooperative arrangements between firms, see Bork (1978), chapter 13. 


\section{(b) The implications of bilateral air service agreements and of antitrust immunity for the International Air Transport Association (IATA)/individual strategic alliances/code-sharing arrangements for competition policy}

As discussed in Section 4 above, bilateral air service agreements are an important factor bearing on the state of competition in the air transport sector generally. Such agreements can also have specific implications for the enforcement of competition law. In particular, where such agreements limit the possibility of entry into international city-pair routes by carriers that have not served that route in the past, they will increase the likelihood that mergers or strategic alliances between incumbent firms serving that route will be viewed with suspicion (since they reduce or eliminate the possibility that an attempt by the merging firms to exercise market power will be defeated by competitive entry). On the other hand, where bilateral agreements adhere to the principle of "Open Skies" and provision is made for the sharing of airport landing and take-off rights to facilitate new entry, a bilateral air service agreement can help to allay concerns regarding potential anti-competitive effects of mergers or alliances (Bingaman, 1996 and Nannes, 1999). This illustrates the interaction between the need for and scope of competition law intervention and the degree of competition that is provided by the applicable regulatory framework. An example of the relevance of bilateral air transport agreements for competition law enforcement is provided in Box 5.

\section{Box 5: The interaction between bilateral air service agreements and competition law enforcement: the British Airways/American Airlines alliance}

In January 1997, British Airways and American Airlines applied to the US Department of Transportation (DOT) for approval to enter into a major new alliance involving extensive code-sharing and coordination of passenger and cargo service between Europe and the US. The proposed alliance was subject to hearings by the Department of Transportation (DOT), with input from the Department of Justice (DOJ). A critical question in the review was how many take-off/landing slots and related facilities would have to be made available for new entrants. The Department of Justice took the position that the DOT could find that the alliance was in the public interest if slots and ground facilities sufficient to allow for 24 daily round trips by other carriers (not party to the alliance) were made available. The DOT proceeding was suspended in the autumn of 1998 when it was determined that the UK was not prepared to come forward with proposals for an open-skies agreement.

In a second round of proceedings, in late 2001, the DOJ urged the DOT to impose various divestitures and other conditions on the proposed airline alliance, in order to protect consumers. At the same time, the Department called for replacement of an existing, restrictive air service treaty between the United States and the United Kingdom with a full 'Open Skies' arrangement which would remove government restrictions on entry and pricing while also emphasizing the need for freeing up airport landing 'slot' allocations. In response to a subsequent decision by the DOT, the two airlines abandoned their proposal. Although plans for a more comprehensive alliance were withdrawn, the two airlines have subsequently engaged in limited code-share arrangements (not covering transatlantic services to London) and continue to participate together in the "Oneworld" alliance.

These developments illustrate the inter-related effects of competition law enforcement and advocacy activities in a deregulated environment, in addition to the potential significance of market-opening agreements.

Source: Nannes (1999), US Department of Justice (2001), Monti (2003) and British Airways (2004).

A further complicating factor in analysing mergers, code-sharing and similar arrangements in the airline industry from the perspective of competition authorities relates to the role of the International Air Transport Association (IATA) and related exemptions for both IATA rate conferences and individual code-share arrangements from national competition laws. The implications of IATAs immunity for competition law enforcement are discussed by Bingaman (1996): 
"Under the [US] Merger Guidelines, we examine the extent to which a merger or joint venture arrangement will increase the likelihood that the firms remaining in the market will be better able to coordinate their behavior in a way that harms consumers.... IATA tariff conferences ... make it easy (and legal) for member carriers to agree expressly on prices in markets where they compete. Thus, the presence of IATA tariff coordination in affected markets may lead the Department to challenge code-sharing between horizontal competitors in situations where otherwise it would not. Moreover, if a proposed code-share agreement has both procompetitive and anticompetitive effects, the Department considers, as part of its overall competitive analysis, whether continued IATA membership is necessary to achieve any benefits and whether withdrawal from IATA would reduce any harm. In particular, we evaluate whether a code-share alliance setting its fares independent of IATA would constitute a less anticompetitive alternative means by which the benefits of the alliance can be achieved."

In 2004, the Competition Directorate-General of the EC Commission undertook a public consultation into the implications of continued exemption of IATA tariff and slot conferences. The consultation process generated numerous inputs from industry and consumer groups (see EC Commission, 2004b and, for background, Stragier, 2002). Subsequently, DG Competition has released a discussion paper in which it refers to the "very high restrictive potential" of IATA Tariff Conferences while also suggesting that any potential consumer benefits from the Conferences are limited (EC Commission 2005a).

With regard to antitrust exemptions for code-sharing arrangements, the question arises as to why an exemption would be needed for arrangements that genuinely provide enhanced service or lower prices for consumers, given that competition authorities recognize the potential for such arrangements to have pro-competitive effects and seek to challenge only those that are detrimental to consumers. In this regard, Bingaman (1996) states as follows:

"It is not necessary for code-share partners to receive antitrust immunity for any agreement that would not violate the antitrust laws; and conduct that would violate the antitrust laws should not be permitted, much less immunized. From our perspective, [the Department of Justice] will continue to review all code-share agreements, including those where the parties seek immunity, and seek to prevent any anticompetitive agreements from being implemented."

\section{(c) Issues concerning the possibility of collusion in this sector, including through electronic tariff publishing and related channels}

A key means through which competition can be thwarted in any industry is that of a cartel (i.e., a price-fixing or market-sharing arrangement). In the past decade and a half, extensive evidence has surfaced that cartels operate in many industries. Moreover, the scope of their operations is often international or even global. Where present, cartels impose heavy costs on all affected economies - especially on developing economies that may lack effective tools to address them. ${ }^{35}$

In the case of the airline sector, collusion or price coordination has sometimes been facilitated by electronic tariff information systems. Such systems provide up-to-the-minute information on fares charged by competing carriers on particular routes. While this can obviously serve important efficiency-related purposes, it can also facilitate price coordination by providing instantaneous information on competitors' responses to fare changes (including both fare-matching and departures from an agreed cartel price). As shown in Box 6, concerns relating to the use of electronic tariff systems (specifically, systems operated by the Airline Tariff Publishing Co.) to facilitate price-fixing have arisen in both the United States and Brazil.

35 In a study prepared for the World Bank, Levenstein and Suslow (2001) found that, in a single year, known cartels operated in industries accounting for up to $\$ 81$ billion in developing countries' imports. Furthermore, where present, cartels increased the price of such imports in the range of 20-30 per cent above competitive levels. International cartels appear to be particularly prevalent in the agri-food sector and in relation to industrial input goods. Such cartels impose a multi-billion dollar burden on developing countries annually, see Evenett (2003). 


\section{Box 6: Allegations of airline price fixing in the US and Brazil: the role of computerized tariff information systems}

In December 1992, the US Department of Justice (DOJ) sued eight of the largest US airlines and the Airline Tariff Publishing Company (ATP) for price fixing and operating ATP, the airlines' jointly-owned fare exchange system, in a way that facilitated collusion. Two specific causes of action were alleged. First, the defendant airlines were alleged to have engaged in various combinations and conspiracies with other airline defendants, including agreements, understandings, and concerted actions to increase fares, eliminate discounted fares, and set fare restrictions for tickets purchased for domestic air travel. Specifically, it was alleged that ATP's computerized fare exchange system had been used to: (i) exchange proposals and negotiate fare changes; (ii) trade fare changes in certain markets in exchange for fare changes in other markets; and (iii) exchange mutual assurances concerning the level, scope, and timing of fare changes. Second, it was alleged that the defendant airlines and ATP had conspired and reached an agreement to operate the system in a way that unnecessarily facilitated coordinated interaction among them in order to (i) communicate more effectively with one another about future fare increases, restrictions, and elimination of discounted fares; (ii) establish links between proposed fare changes in one or more city-pair markets and changes in other markets; and (iii) monitor each other's changes, including changes in fares not available for sale, and (iv) reduce uncertainty about each other's pricing intentions. In the event, a negotiated consent decree with the parties required the defendants to institute an anti-collusion compliance program and restricted their ability to communicate proposed fare changes through ATP for a period of ten years.

According to Owen (2003), years later, a similar set of concerns, possibly involving electronic tariff publishing and more traditional forms of collusion, arose in Brazil. In August 2003, the presidents of Brazil's four major airlines met together in a hotel. Five days after the meeting, the fares charged by all four airlines for flights between the central airports of Rio de Janeiro and Sao Paulo increased by 10 per cent. Subsequently, the airlines argued that the price increase was attributable not to any actual collusion but to independent "price-matching" facilitated by electronic tariff filing.

Source: McDonald (2004) and Owen (2003).

The foregoing is not, however, to deny that electronic tariff systems can provide major efficiency and consumer benefits. In a more recent case, the US Department of Justice analysed the question of whether practices of Orbitz, a travel website owned by five major domestic airlines, were likely to facilitate price coordination. Of particular interest was a "most favored nation" (MFN) clause that required the owners and charter associates of Orbitz to provide it with any publicly available fares that the carriers listed on their own websites or on other online travel sites. The Department of Justice found that this clause did not result in higher fares or create market dominance for Orbitz (McDonald 2004).

\section{(d) The treatment of predatory conduct and exclusionary practices in the airline sector}

A further important aspect of the application of competition policy and rules in the air transport sector concerns the treatment of predatory or exclusionary practices (i.e., practices through which firms may seek to exclude potential rivals from markets). These are practices that may be employed by incumbent firms to drive competing firms out of the market or (perhaps more frequently) to prevent entry by new competitors. The practices employed may include selective price cuts, targeted expansions of capacity, the exercise of control over access to necessary infrastructure (e.g., in the case of airlines, take-off and landing slots, counter facilities, etc.) and other actions. 
Generally speaking, competition authorities approach allegations of predatory conduct with a degree of scepticism. This reflects a widespread view, supported by relevant scholarly literature, that predatory strategies are costly to implement and uncertain in the pay-offs that they yield (for development of this basic perspective, see Easterbrook (1981) and references cited therein). More specifically, enforcement experience and relevant literature highlight that efforts to exclude existing or potential competitors from a market through price-cutting or capacity expansions are unlikely to be profit-maximizing strategies for the firms involved in the absence of barriers that prevent subsequent entry (or re-entry) of competitors when the alleged predator(s) eventually seeks to raise its prices above competitive levels (as it must do eventually if its losses from the period of predation are to be recouped). In some jurisdictions this has led to the adoption of legal approaches to the assessment of alleged predatory conduct that emphasize the identification of such barriers and the feasibility of "recoupment" as a necessary condition for a finding of predation (see, for example, the leading US decision on this matter, Brooke Group Ltd. v. Brown and Williamson Tobacco Corp., 509 U.S. 209, 113 S. Ct. 2578 (1993)).

Nonetheless, modern approaches to competition law enforcement at least recognize the possibility that predation may be a viable strategy for incumbent firms, in some circumstances. This is based, in part, on the view that a "reputation for predation" may itself serve as the necessary barrier to post-predation entry, at least in some cases (Milgrom and Roberts, 1982). In this regard, Nannes (1999) argues that the airline industry may be more than usually susceptible to successful predation:

"The airline industry exhibits certain characteristics that make a predatory theory more than merely "plausible." First, hub carriers dominate hub markets, as demonstrated by market share. Second, hub carriers appear to be in a position to exact high fares, as demonstrated by hub premiums. Third, hub carriers can easily respond to entry by start-up carriers by increasing capacity and reducing fares in affected markets virtually overnight. Fourth, hub carriers have an incentive to act before start-up carriers develop a foothold in the hub: it is obviously easier to drive a carrier out before it gets established in the market. Fifth, a start-up carrier is likely to have limited capital and is thus vulnerable to predatory practices.... Sixth, a hub carrier "defending its turf" against encroachment by a start-up carrier in a few markets can create a "reputation for predation" that deters start-up carriers from entering its many other hub markets; this can significantly alter the "cost-benefit" predation calculation for a hub carrier in a way uncharacteristic of most other industries. In short, a "recoupment scenario" is not implausible at all."

The view that the airline industry is particularly susceptible to predatory pricing is not shared by all observers (see, for sceptical perspectives, Bamberger and Carlton, 1999 and Lall, 2005). Nonetheless, in recent years, the airline industry has been the focus of repeated allegations of predatory conduct and the possibility of predation has been widely viewed as a problem worthy of attention in this industry (Nannes, 1999; Fones, 1997; Ross and Stanbury, 2001 and Stragier, 2002).

It is noteworthy, though, that proven instances of successful predation remain rare. In the US, the Tenth Circuit Court of Appeals upheld a district court's grant of summary judgment for the defendant in a high-profile case of alleged predation against American Airlines (U.S.V. AMR Corp., 335 F.3d 1109 (10th Cir. 2003)). In Canada, allegations that Air Canada had engaged in predatory acts against two low-cost start-up carriers (West)et and CanJet) in 2000 and 2001 were recently settled (see Box 7).

A different set of issues falling in the broad category of (potential) exclusionary practices is raised by airline frequent flier (loyalty) programmes, which were introduced in the US in the early 1980s and were adopted by the majority of carriers providing transcontinental service in the 1990s. ${ }^{36}$ While popular with consumers (especially business travellers), such programmes raise potential concerns from the standpoint of competition and economic efficiency. In economic-theoretic terms, such programmes take advantage of a principalagent problem resulting from the fact that, especially for business travel, fares and schedules are frequently travel selected by parties other than those responsible for payment (Levine, 1987). They create strategic

36 A closely-related set of issues is raised by the role of incentive arrangements provided by airlines for travel agents. For discussion, see Borenstein (1992) and Ross and Stanbury (2001). 
advantages for larger airlines or inter-firm alliances in that the value of the rewards generated to individual flyers is enhanced by the range of markets served. They also reduce the threat of potential competition, by enhancing travellers' costs (in terms of foregone rewards) of switching to alternative carriers (Borenstein, 1992). Reflecting such concerns, the use of a frequent flier program in Swedish domestic air transport has been condemned by the Swedish Competition Authority (Arhel, 2004).

\section{Box 7 : Allegations of predatory conduct in Canadian airline markets}

In March 2001, the Canadian Commissioner of Competition filed an application with the Competition Tribunal seeking an order prohibiting Air Canada from operating flights on certain routes in eastern Canada at fares that did not cover their avoidable costs. For convenience, the case was divided in two parts. Phase one dealt with the application of an "avoidable cost test" in such cases. Phase two would have determined if Air Canada had actually engaged in culpable conduct under section 79 of the Canadian Competition Act dealing with abuse of a dominant position.

In June 2003, the Tribunal released its decision regarding phase one of the case. The Competition Bureau, which supports the Commissioner, has indicated that it believes that the principles established in the decision will be relevant for future cases of a similar nature. However, in light of the passage of time and significant changes that had occurred in the industry, the Commissioner decided that it would not be in the public interest to pursue the second phase of the case.

Source: Canada, Competition Bureau (2004)

On the other hand, the argument has been made that depending on factors such as market shares and the wider competitive environment, frequent flier programmes can sometimes enhance the financial performance of carriers and thereby enable them to cover their fixed costs without generating adverse consequences for efficiency and competition (Liu et al., 2000).

\section{(e) The evolution of national and international policies governing the air transport sector: the potential contribution of competition advocacy activities}

As emphasized in other parts of this study, competition and efficiency in the air transport sector depend significantly on national and international policies governing market access and foreign investment in this sector in addition to the competitive strategies of firms and related responses by competition authorities. Although broadly speaking, in the past two decades the international air transport sector has evolved in favour of freer entry and pricing, many obstacles to competition remain, particularly those embodied in national polices and bilateral air service agreements that limit entry, foreign investment and the services that foreignbased carriers can provide. As noted, questions have also been raised about the implications for competition and consumer welfare of continued exemption for IATA rate conferences from national competition laws.

Such issues clearly go beyond the role of competition law enforcement, in that they are principally concerned with government measures that affect competition and implicate decisions by national legislatures and other policy-making bodies. Nonetheless, competition authorities may have a role to play in relation to these questions as well. Competition authorities often provide valuable input to wider policy questions impinging on competition and the efficient functioning of markets, through their advocacy functions. The term "advocacy functions" refers to the role of competition authorities in providing input to public policy development processes, especially processes potentially impacting on the operation of markets, whether through testimony before legislative committees, intervention in public hearings or regulatory proceedings, the preparation of research studies, or other means. This is a well-established role of competition agencies at least in many jurisdictions (Anderson and Jenny, 2005). Indeed, in the past, the reform of government 
measures affecting competition in the airline sector has been a key focus of competition advocacy activities at the national level, at least in the United States and Canada (Anderson et al., 1998). The pursuit of similar reforms at the international level could imply the commissioning of research and the conduct of advocacy activities aimed at promoting further pro-competitive changes, both nationally and internationally. Experience suggests that such "cooperation to promote competition" will be vital to establishing more efficient air transport systems internationally and particularly in the developing world, as discussed in the conclusion of the previous Section.

For competition advocates, a natural focus of attention concerning the air transport sector is the restrictions on foreign investment that are embodied in relevant regulatory legislation of many countries. More broadly still, in research undertaken for a recent official review of the Canadian Transportation Act and related policies and regulations, Ross and Stanbury (2001) have raised the fundamental question whether consumers are well served by the present network of often-restrictive bilateral air service agreements, underpinned by the 1944 Chicago Convention, which constitute the core of the international regime for civil aviation. Ross and Stanbury (2001) state:

"The "Chicago system" is a closed one - access to international air travel markets is granted only by governments (usually on a reciprocal basis) by means of bilateral agreements. It is not too strong to say that all international trade in aviation services is forbidden, except that which is specifically permitted in a web of bilateral agreements. The system is an utter anomaly to the world's fast liberalizing trading system. It is based on the economic ideas of mercantilism which focus on the protection and promotion of domestic economic interests."

In a similar vein, Havel (1997) observes that "There is ... a basic systemic incompatibility between the Chicago idea of zero sum diplomatic exchanges and a free market system ...".

Clearly, the foregoing observations go beyond the purview of competition authorities and competition policy per se. The issue raised by Ross and Stanbury (2001) is whether the world community can find a better approach to governance of the international passenger air transport sector than the present patchwork of (in many cases) restrictive bilateral agreements. Taking the point further, Ross and Stanbury (2001) themselves suggest that "There is no serious reason why air travel should not be part of WTO agreements". Of course, this is a multi-faceted question which, if at all, would need to be resolved by WTO Members collectively (see related discussion in Section 6 below). To the extent, however, that competition authorities concern themselves with all measures that impede the competitive process to the detriment of consumers, they may have a contribution to make in advocating reforms in this area, as well.

Apart from the issue of competition advocacy regarding the policy framework for the international air transport sector, a further set of questions concerns the possibility of enhanced coordination in the application of national competition policies and legislation in this and other sectors. As is evident from the above discussion of the treatment of international airline mergers and strategic alliances, in many cases the resolution of concerns regarding the competitive effects of such arrangements will implicate the laws and enforcement authorities of more than one jurisdiction. In such circumstances, the potential arises for conflicts in enforcement approaches. More broadly, it may be argued that expanded cooperation arrangements, whether in the WTO or another forum, are needed to address the international collective action problems that are posed by transnational cartels, mergers and abuses of a dominant position in diverse industries (see, for related background, Clarke and Evenett, 2003, Birdsall and Lawrence, 1999, Anderson and Jenny, 2005). Such arrangements may be particularly important to protect the interests of smaller developing countries that are especially vulnerable to anti-competitive practices and are not party to the existing bilateral cooperation arrangements that link the competition authorities of major developed countries. For the present, however, WTO Members have clearly decided against initiating any negotiations on this issue in the framework of the WTO, as part of the current round of multilateral negotiations (the Doha Round). ${ }^{37}$

37 Decision adopted by the WTO General Council on 1 August 2004 (WT/L/579, 2 August 2004). 


\section{(f) Concluding remarks}

Measures to address private anti-competitive practices are an important adjunct to efforts to liberalize international air transport markets. As outlined in this Section and in the related discussion of past experience with deregulation in the US domestic airline industry, extensive experience indicates that the potential benefits of liberalization/freer entry in airline markets will be eroded if carriers are permitted to create unwarranted market power through mergers, joint ventures and strategic alliances or to collude or engage in predatory or other anti-competitive actions. The logical response to this concern is the implementation of competition laws administered by competent authorities. As indicated in this Section, the sound application of competition law in this sector does not involve sweeping intervention or blanket prohibition of practices such as mergers or code-sharing that can, depending on the circumstances, generate significant efficiency gains and benefits for consumers; rather, it requires a discerning approach by relevant authorities which deals with structural amalgamations or conduct that are genuinely harmful to competition without coming in the way of efficient inter-lining arrangements, necessary re-structuring or pro-competitive pricing and other practices. Competition authorities also have a role to play in promoting wider policy changes to promote competition and efficiency in the airline sector, through their advocacy functions. This is another respect in which the role of competition policy can contribute to and reinforce the goals of international trade liberalization.

\section{GOVERNANCE OF THE INTERNATIONAL AIR TRANSPORT INDUSTRY}

The first attempt at governing international air transport took place shortly after the first manned airplane flight in 1903. Although no agreement was reached, this attempt set the stage for a number of additional conferences aimed at regulating international air transport. The most important achievement in this area was the successful conclusion of the 1944 Chicago Conference. The outcome of that conference is known as the Chicago Convention and is still in effect today. It has set the stage for how countries regulate international air traffic in order to meet their specific national objectives.

Despite its longevity, the Chicago Convention has come under criticism as a constraint to the development of international air transport. To some, the system developed in 1944 was deemed not conducive to the evolving and changing nature of the air transport industry. In 1946 the United States and the United Kingdom concluded a bilateral agreement known as Bermuda I. As a result of conflicting views about its contents, the overall result was a cautious bilateral agreement that provided for substantial government intervention in the establishment of routes, capacity and tariffs. Since then the system has evolved to the point where by June 2004, more than 3,500 bilateral agreements have been signed involving more than a 100 countries. In addition, in 1995 the General Agreement on Trade in Services (GATS), which is administered by the World Trade Organization (WTO) came into effect. As a result, a number of different bilateral, regional and multilateral instruments exist today, creating a complex system of governance. The purpose of this Section is to review the different approaches to market access and identify a set of issues facing policy makers at the international level.

Regulating international air transport has traditionally involved policies covering market access, pricing and capacity. Recent bilateral agreements, however, have liberalized many aspects of pricing and capacity, leaving market access as one of the principal issues that is still heavily regulated. The next Subsection reviews market access issues. This is followed by an examination of the trend by countries to sign bilateral agreements and how air transport is treated in the GATS. 


\section{(a) Bilateral 'Open Skies' and regional agreements}

As explained above, the international air transport system is governed by a system of bilateral agreements. In 1992, however, when the United States signed a bilateral with the Netherlands containing more liberal provisions than the existing bilaterals, the term 'open skies' was coined. This term is to a large extent a misnomer, since it reflects the fact that the agreements are more liberal, but does not mean that they provide binding access to the parties in respect of all the freedoms listed in Box 3.

Nevertheless, when compared to the existing regime the US initiative was clearly a step toward liberalization, albeit in a discriminatory fashion against third countries. By 2002, the United States had signed 59 open skies bilateral agreements. The main principles of the open skies agreements are outlined in Table 7. Open Skies agreement are not limited to the United States. A number of countries have also signed such agreements (Table 8).

Table 7

Main open skies principles

\begin{tabular}{ll}
\hline \multicolumn{1}{c}{ Combined passenger/cargo services } & \multicolumn{1}{c}{ All-cargo services } \\
\hline $\begin{array}{l}\text { Complete exchange of the five basic traffic rights } \\
\text { (including 5th freedoms) }\end{array}$ & $\begin{array}{l}\text { Same liberal provisions on traffic rights and rates (same regime as } \\
\text { for combination carriers) }\end{array}$ \\
$\begin{array}{l}\text { Free market access for designated carriers } \\
\text { (free determination of routes, capacity, frequency) }\end{array}$ & $\begin{array}{l}\text { Pro-competitive' ground support } \\
\text { (self-handling, intermodal rights, user charges) }\end{array}$ \\
$\begin{array}{l}\text { Freedom of fares and rates } \\
\text { (double-disapproval if threat to competition) }\end{array}$ & $\begin{array}{l}\text { Liberal treatment of non-scheduled cargo services } \\
\text { (the least restrictive charter regulations of the two countries } \\
\text { apply) }\end{array}$ \\
\hline
\end{tabular}

Source: OECD, DSTI/DOT (99), 1 June 1999.

Despite the step towards liberalization created by the implementation of the open skies agreements, there are many detractors who claim that they do not go far enough. ${ }^{38}$ Of particular concern to these critics is the absence of rights beyond the Fifth Freedom. They also retain the concept of national carriers, which in many cases is never defined as majority foreign owned carriers. The agreements can also best be described as "positive list" - no international traffic is permitted, unless specified otherwise.

Approaches to liberalizing international air transport have not been restricted to bilateral agreements. A number of regional agreements have recently been adopted. These are listed in Table 9, along with an indication of the extent to which they provide Fifth Freedoms. A notable aspect of the information in the table is the number of agreements among developing countries.

An interesting complement to the existing network of bilateral and plurilateral approaches is the adoption by the economies of the Asia Pacific Economic Co-operation (APEC) of eight principles on air transport liberalization. ${ }^{39}$ Seven members of APEC went further and adopted a regional open skies agreement based on these principles (Findlay, 2003). ${ }^{40}$

The external relations agenda for air transport which was put forward by the EC Commission in March 2005 would go beyond existing Open Skies arrangements to create a "common airspace" with the EU's neighbouring countries in the Mediterranean and along its eastern borders, operating under common security and safety rules. As a second major element of its agenda, the Commission has signalled an intention to negotiate major new agreements to create an "open air space" with the United States and to establish liberalized trade in air transport services with Russia and China. In addition, existing bilateral agreements between Member States and non-EU countries would be brought into conformity with European law (see EC Commission, 2005b and 2005c).

38 For example, the International Chamber of Commerce in its statement "The need for greater liberalisation of air transport", 7 December, 2005. (http://www.iccwbo.org/home/statements_rules/statements/2000/need_for_greater_liberalization.asp).

39 An overview of the approach taken by APEC to air transport liberalization can be found at: www.icao.int/icao/en/atb/ecp/ CaseStudies/ApecConsensus_En.pdf.

40 Details of the agreement can be found at: http://www.maliat.govt.nz. 
Table 8

Open skies agreements completed, 2002

\begin{tabular}{|c|c|c|c|}
\hline 1992 & Netherlands - United States & 1998 & Turkmenistan - United Arab Emirates \\
\hline 1995 & Austria - United States & 1998 & United Arab Emirates - Uganda \\
\hline 1995 & Belgium - United States & 1998 & Uzbekistan - United States (7C) \\
\hline 1995 & Czech Republic - United States (7C, T) & 1999 & Argentina - United States (7C, FN, SS, T) \\
\hline 1995 & Denmark - United States & 1999 & Bahrain - United States (7C) \\
\hline 1995 & Finland - United States & 1999 & Chile - Costa Rica (R) \\
\hline 1995 & Iceland - United States (7C) & 1999 & Dominican Republic - United States (7C) \\
\hline 1995 & Luxembourg - United States (7C) & 1999 & Ireland - New Zealand $(7,8, R)$ \\
\hline 1995 & Norway - United States & 1999 & New Zealand - Peru (7C, FE S) \\
\hline 1995 & Sweden - United States & 1999 & New Zealand - Switzerland $(O, R)$ \\
\hline 1995 & Switzerland - United States & 1999 & Pakistan - United States (7C) \\
\hline 1996 & Germany - United States (7C, FN) & 1999 & Portugal - United States $(7 C, T)$ \\
\hline 1996 & Jordan - United States & 1999 & Qatar - United States (7C) \\
\hline 1997 & Aruba - United States (7C) & 1999 & Tanzania, United Rep. of - United States (7C, T) \\
\hline 1997 & Brunei Darussalam - Singapore (S) & 1999 & United Arab Emirates - United States (7C) \\
\hline 1997 & Brunei Darussalam - United States $(7 \mathrm{C}, \mathrm{S})$ & 2000 & Australia - New Zealand $(7 \mathrm{C}, 8, \mathrm{FF}, \mathrm{O})$ \\
\hline 1997 & Chile - United States (7C, S) & 2000 & Benin - United States (7C) \\
\hline 1997 & Costa Rica - United States & 2000 & Burkina Faso - United States (7C) \\
\hline 1997 & El Salvador - United States (7C) & 2000 & Cook Islands - New Zealand (O) \\
\hline 1997 & Guatemala - Panama & 2000 & Gambia - United States $(7 C, T)$ \\
\hline 1997 & Guatemala - United States (7C) & 2000 & Ghana - United States $(7 C, T)$ \\
\hline 1997 & Honduras - United States (7C) & 2000 & Malta - United States $(7 \mathrm{C}, \mathrm{T})$ \\
\hline 1997 & Kenya - Netherlands & 2000 & Morocco - United States $(7 \mathrm{C}, \mathrm{T})$ \\
\hline 1997 & Malaysia - New Zealand (O, FF) & 2000 & Namibia - United States (T) \\
\hline 1997 & Malaysia - United States $(7 \mathrm{C}, \mathrm{T})$ & 2000 & New Zealand - Samoa $(\mathrm{O}, \mathrm{S}, \mathrm{T})$ \\
\hline 1997 & Netherlands Antilles - United States (7C) & 2000 & Nigeria - United States $(7 \mathrm{C}, \mathrm{T})$ \\
\hline 1997 & New Zealand - Singapore (7C, FF O, S) & 2000 & Rwanda - United States (7C, FN, T) \\
\hline 1997 & New Zealand - United States (7C, FN, S) & 2000 & Senegal - United States $(7 \mathrm{C}, \mathrm{FN}, \mathrm{T})$ \\
\hline 1997 & Nicaragua - United States (7CC) & 2000 & Slovakia - United States $(7 \mathrm{C}, \mathrm{T})$ \\
\hline 1997 & Panama - United States (7C) & 2000 & South Africa - Zimbabwe \\
\hline 1997 & Romania - United States $(\mathrm{T})$ & 2000 & Turkey - United States $(\mathrm{T})$ \\
\hline 1997 & Singapore - United States (7SC, S) & 2001 & Cook Islands - Samoa \\
\hline 1997 & Chinese Taipei - United States & 2001 & France - United States (7C, FN) \\
\hline 1998 & Brunei Darussalam - New Zealand (7, 8, FF, O,S) & 2001 & Oman - United States $(7 \mathrm{C}, \mathrm{T})$ \\
\hline 1998 & Chile - New Zealand (7C, FF O, R, S) & 2001 & Poland - United States (7C, FN, T) \\
\hline 1998 & Chile - Panama & 2001 & Samoa - Tonga \\
\hline 1998 & Denmark - New Zealand (FF) & 2001 & Sri Lanka - United States M \\
\hline 1998 & Ethiopia - United Arab Emirates & 2002 & Cape Verde - United States (7C, FN) \\
\hline 1998 & Italy - United States & 2002 & Chile - Peru $(T, S)$ \\
\hline 1998 & New Zealand - Norway (FF) & 2002 & Jamaica - United States $(\mathrm{T})$ \\
\hline 1998 & New Zealand - Sweden & 2002 & New Zealand - Tonga $(7, \mathrm{FF}, \mathrm{O})$ \\
\hline 1998 & Peru - United States $(7 C, S, T)$ & 2002 & Singapore - United Arab Emirates (7) \\
\hline 1998 & Republic of Korea - United States & 2002 & Uganda - United States (7C, FN) \\
\hline
\end{tabular}

Note: 7 denotes "Seventh Freedom" rights for all services; 7C, 7CC and 7SC denote "Seventh Freedom" rights for all-cargo, charter allcargo and scheduled all-cargo services; 8 denotes "Eighth Freedom" rights for all services; FF denotes a free pricing scheme; FN denotes a double disapproval tariff scheme without tariff filing requirements: $O$ denotes a liberal ownership provision; $R$ denotes an existence of provisions less liberal than comparable ones in other open skies agreements; S denotes suspension due to entry into force of the "Korea" Agreement (and its Protocol in some cases); SS denotes suspension by one of the parties; and T denotes the existence of a transition annex or similar clause.

Source: ICAO. 
Table 9

Regional agreements with fifth freedom rights

\begin{tabular}{|c|c|c|c|c|c|c|c|}
\hline $\begin{array}{c}\text { Andean Pact } \\
1991 \\
\text { (5 States) }\end{array}$ & $\begin{array}{c}\text { Caribbean } \\
\text { Community } \\
\text { (CARICOM) } \\
1996 \\
\text { (14 States) }\end{array}$ & $\begin{array}{c}\text { Fortaleza } \\
\text { Agreement } \\
1997 \\
\text { (6 States) }\end{array}$ & $\begin{array}{c}\text { Banjul Accord } \\
1997 \\
\text { (6 States) }\end{array}$ & $\begin{array}{c}\text { CLMV } \\
\text { Agreement } \\
1998 \\
\text { (4 States) }\end{array}$ & $\begin{array}{c}\text { COMESA } \\
1999 \\
\text { (21 States) }\end{array}$ & $\begin{array}{c}\text { ACAC } \\
1999 \\
\text { (16 States) }\end{array}$ & $\begin{array}{c}\text { MALIAT } \\
2001 \\
\text { (7 States) }\end{array}$ \\
\hline Fifth: Yes & $\begin{array}{l}\text { Fifth: To be } \\
\text { exchanged on } \\
\text { a reciprocal } \\
\text { and liberal } \\
\text { basis between } \\
\text { members. }\end{array}$ & $\begin{array}{l}\text { Carriage of } \\
\text { Fifth Freedom } \\
\text { traffic permitted } \\
\text { only with } \\
\text { consent of } \\
\text { States } \\
\text { concerned. }\end{array}$ & $\begin{array}{l}\text { Fifth: Yes, } \\
\text { unrestricted } \\
\text { where no } \\
3^{\text {rd }} \text { and } 4^{\text {th }} \\
\text { Freedom } \\
\text { operations; } \\
\text { limited to } 20 \% \\
\text { of capacity } \\
\text { with 3rd/4th; } \\
\text { reciprocal for } \\
\text { non-African } \\
\text { carriers. }\end{array}$ & $\begin{array}{l}\text { Fifth: No } \\
\text { limitation on } \\
\text { traffic. }\end{array}$ & $\begin{array}{l}\text { Fifth: Unrestric- } \\
\text { ted where there } \\
\text { are no 3rd and } \\
\text { 4th freedom } \\
\text { operations. } \\
\text { Initially, there } \\
\text { are } 30-40 \% \\
\text { capacity limita- } \\
\text { tions on } 3^{\text {rd }} \text { and } \\
\text { 4th Freedoms. } \\
\text { Eventually there } \\
\text { will be no restric- } \\
\text { tions. }\end{array}$ & $\begin{array}{l}\text { Fifth: No } \\
\text { restrictions } \\
\text { by } 2005 .\end{array}$ & Fifth: Yes \\
\hline
\end{tabular}

Source: WTO based on ICAO data.

Aside from the architecture of the bilateral agreements, another question is the nature of discrimination generated by these agreements. The issues here are similar to those raised by the spread of regional trading agreements - whether or not a multilateral, or discriminatory bilateral and regional agreements are best suited for trade in air transport services (WTO, 2004). As in the case of merchandise trade agreements, very little can be concluded a priori about the welfare implications of discriminatory agreements. The new generation of agreements are more liberal, but we cannot say whether or not a more open air transport system would exist if the multilateral approach had been pursued.

\section{(b) The WTO General Agreement on Trade in Services}

The bilateral approach to regulation in air transport is not unique among the modes of transport. International road transport is also dominantly organized in the form of 50/50 bilateral cargo sharing agreements. Negotiators of the GATS have not excluded road transport from the scope of the GATS. Rather, WTO Members have simply used the flexibilities offered by the GATS to maintain these agreements as exceptions to the most favoured nation principle. ${ }^{41}$ In the case of aviation however, Members chose a different route. They decided to exclude from the purview of GATS the core of commercial air transport - the "hard rights" or traffic rights and the services directly related to the exercise of traffic rights.

Members nevertheless decided that the GATS shall apply to measures affecting three services relevant to air transport - namely: (a) aircraft repair and maintenance services; (b) the selling and marketing of air transport services; and (c) computer reservation system (CRS) services. Between 25 and 45 original Members of the WTO - depending on the service and the modes of delivery concerned - have undertaken commitments for these services, while relatively numerous MFN exemptions have been listed, in particular in the area of computer reservation systems (16) and of the selling and marketing of air transport services (17). ${ }^{42}$ Accessions of new Members to the WTO since 1995 have only marginally changed this picture.

In addition, even in the services covered by the scope of the GATS, Members have agreed on a "grandfathering" provision whereby any specific commitment or obligation assumed under the GATS shall not reduce or affect a Member's obligations under bilateral or multilateral agreements that are in effect on the date of entry into force of the WTO Agreement. Furthermore, they have agreed on a provision regarding the exhaustion of pre-existing dispute settlement provisions, such that the dispute settlement procedures of the WTO may be invoked only where obligations or specific commitments have been assumed by the concerned Members, and

41 Coupled with an absence of commitments on cross-border supply of road transport since such a commitment would have been granted to all WTO members.

42 Further details on the commitments undertaken by Members in these areas can be found in WTO (2001) 
where dispute settlement procedures in bilateral and other multilateral agreements or arrangements have been exhausted. These two provisions have no equivalent in any other services sector. They have not been tested, since so far no dispute settlement cases on air transport services have arisen. Neither have they been the subject of any discussion among members since the entry into force of the Agreement.

The question of the coverage of air transport services by the GATS has been the subject of many controversial discussions and diverging views. The parameters of this discussion are the following:

- Paragraph 1 of the Annex on Air Transport Services (which has the same legal value as the GATS agreement itself), stipulates that the Annex "applies to measures affecting trade in air transport services, whether scheduled or non-scheduled, and ancillary services". While "measures affecting trade in services" have been widely defined by subsequent dispute settlement cases, "trade in air transport services" is not defined and nor are "ancillary services";

- Paragraph 2 of the Annex stipulates that the Agreement, including its dispute settlement procedures, shall not apply to measures affecting: (a) traffic rights, however granted; or (b) services directly related to the exercise of traffic rights. While traffic rights are extensively and precisely defined by the Annex, ${ }^{43}$ "services directly related to the exercise of traffic rights" have not been defined at all.

The divergence of views among Members on approaches to the coverage of air transport services by the GATS arises from this absence of definitions. The problem is further complicated by the absence of a clear distinction between the general exclusion (traffic rights and services directly related to the exercise of traffic rights) and the exception to that exclusion (the three covered services), as well as by the lack of any link between the classification of the Annex and the classification generally used for all other services.

These inconsistencies are reflected in the schedules of Members' commitments. An analysis of the commitments undertaken by Members shows that some of these go beyond the three services listed in the Annex. Some of the scheduled services appear in the air transport part of the non-compulsory classification used by most Members in most sectors - the Central Product Classification of the United Nations (CPC) and its abbreviated version in GATS document MTN/GNS/120. Wet leasing is one such example. Other commitments in the schedules cover services not listed in the CPC under air transport sevices, such as ground handling (services auxiliary to all modes of transport), freight forwarding (ibidem), storage and warehousing (ibidem), financial leasing (financial services), dry leasing (business services), franchising (distribution services) and catering (hotels and restaurants services). In other instances, Members have excluded from their commitments the air transport part of a given service, such as aerial advertisement from advertisement, flight training school from adult education, or catering from hotels and restaurants. Finally, some Members have felt it necessary to list MFN exemptions on some of these services, such as ground handling. So far, no dispute has arisen regarding these commitments.

The text of the Annex was heavily negotiated, particularly regarding its coverage. An agreement could only be achieved at the time on this question through the inclusion of a review clause contained in paragraph 5 of the Annex. This review clause stipulates that "[T]he Council for Trade in Services shall review periodically, and at least every five years, developments in the air transport sector and the operation of this Annex with a view to considering the possible further application of the Agreement in this sector."

The first of these reviews was held between September 2000 and November 2003, essentially during four dedicated meetings of the regular session of the Council for Trade in Services. These extensive debates ${ }^{44}$ have

43 "Traffic rights" mean the right for scheduled and non-scheduled services to operate and/or to carry passengers, cargo and mail for remuneration or hire from, to, within, or over the territory of a Member, including points to be served, routes to be operated, types of traffic to be carried, capacity to be provided, tariffs to be charged and their conditions, and criteria for designation of airlines, including such criteria as number, ownership, and control.

44 The complete reports of these four dedicated meetings can be found in documents S/C/M/49 dated 1 December 2000, S/C/M/50 dated 5 March 2001, S/C/M/57 dated 13 February 2002 and S/C/M/62 dated 17 October 2002 and the complete documentation provided by the WTO secretariat for those meetings in documents S/C/W/163 and its 6 addenda (dated respectively 3 August 2000, 25 October 2000, 10 November 2000, 13 August 2001, 15 August 2001, 13 August 2001 and 16 August 2001), as well as in documents S/C/W/200 dated 3 October 2001 and S/C/W/200 Add 1 dated 28 February 2002. 
led to no consensus with regard to any possible clarification of the existing scope of the Annex, nor with regard to any possible extension of the scope of the GATS to the air transport sector.

On the one hand, several Members contended that since the Annex only excluded the "services directly related to the exercise of traffic rights", services not directly related to the exercise of traffic rights were already included in the scope of the GATS. This was termed the "grey area" concept, whereby a range of services would neither fall into any of the three explicitly covered services (aircraft repair and maintenance services, the selling and marketing of air transport services, computer reservation systems services) nor be included in traffic rights or services directly related to the exercise of traffic rights.

In the absence of a definition of what constitutes a "service directly related to the exercise of traffic rights" those Members suggested a functional test: was retaining traffic rights necessary to undertake the activity concerned? From this test, they concluded that services such as catering, leasing, ground handling, airport management services, and freight forwarding services for air transport were not related to the exercise of traffic rights and therefore already covered by the GATS. These Members therefore called for commitments in such areas as ground handling services and airport management services in the context of the Doha negotiations.

Furthermore, some of them argued in favour of the extension of the coverage of GATS to "hard rights" activities such as all cargo transport services (referring notably to the substantive work of the OECD in that regard), charter services, and domestic air transport services (seen as a mode 3 establishment issue rather than in terms of traffic rights). They also suggested building on the work of the International Civil Aviation Organization (ICAO) on overflight and technical landing operational rights, provisions on access to/use of airport and air navigation facilities and services, remittances of earnings, and movement of personnel, in a fashion similar to that by which the WTO TRIPS Agreement built on the work of the World Intellectual Property Organization (WIPO). In order to address the problem of MFN and traffic rights these Members suggested approaches such as transition periods, conditional MFN (as in the WTO Plurilateral Agreement on Government Procurement) and plurilateral agreements.

On the other hand, in the review exercise many other Members invoked the negotiating history and argued that the GATS only applied to the sectors explicitly listed by paragraph 3 of the Annex. In their view, there was no space for a "grey area," since the three covered sectors were an exception to the general exclusion of traffic rights and of services directly related to the exercise of traffic rights ("except as provided in paragraph 3 of the Annex"). In this view, there was therefore no point in clarifying the scope of the Annex .

An even greater number of Members opposed any extension of the scope of the GATS on the grounds that the rationale of its existing scope had not changed and that liberalization was occurring anyway in a bilateral, regional and plurilateral context. It was further argued that because of its universality and links that would be made with other subjects in the negotiations, multilateral liberalization would act as a brake on the ongoing autonomous process of liberalization. ${ }^{45}$ Those inclined to this view also considered that the ICAO was the proper forum to discuss these questions. They added that the GATS had not had any discernible effects on liberalization in regard to the three covered services, whereas liberalization was taking place outside the purview of GATS for hard rights. This was one more reason not to extend the scope of GATS.

The only agreed conclusion of this review was "to decide that the formal commencement of the second review [would] take place at the last regular meeting of the Council for Trade in Services of 2005 [and that this should not] prejudge Members' interpretation of paragraph 5 [the review clause] of the Annex."

45 For a detailed account of the liberalization process see notably document S/C/W/163 add 3 dated 13 August 2001 and the annual publication of ICAO "The World of Civil Aviation". 


\section{CONCLUSIONS}

Air transport is a vital and increasingly important component of the international trading system, both in terms of its direct contribution to international trade and as a facilitator of international trade in goods and services in other sectors. The growth in the industry over the past 30 years has been remarkable, attributable in large measure to technological innovations in terms of aircraft capacity and performance, combined with significant deregulatory and liberalisation initiatives.

The structure of the air transport services industry has changed in interesting ways over the last several decades, some of which pose significant questions for developing countries that rely on air transport for trade. Quite apart from the task of securing adequate and competitively priced air transport services to ensure export development and growth, developing countries may be challenged by the structural evolution of the industry in the future. Monitoring and reacting to these trends should constitute an important component of development planning.

The industry is engaged in a continuing struggle to define the terms of competition. Policy initiatives have markedly changed the industry from what it was 30 years ago. The introduction of competition has resulted in a growth in equity and non-equity alliances across the globe, expanded the range of routes being served, and lowered airfares. Recognition of the desirability of competition has also resulted in the entry of Low Cost Carriers into the industry, with the result that air transport services have been extended to a broader consumer base. All these changes have occurred within a regulatory framework premised on insistence that expansion of the industry must take place in an environmentally responsible manner.

The regulatory process based on bilateral agreements, conceived in 1944, is under pressure as it tries to cope with the pace of change in the industry. The predominant regulatory response to this pressure has been to maintain the bilateral system, but to relax many of the provisions in these agreements. This process has been widely welcomed and the debate will continue as to whether or not the bilateral process is sufficient to meet the needs of the industry. A number of countries have concluded that the answer is no and complemented their network of bilateral agreements with plurilateral agreements. Market access in the air transport sector is unique in its treatment within the WTO. To date, WTO Members have largely excluded the issue from the GATS agreement, but are continuing to seek a better understanding of how multilateral cooperation and rules can best serve the industry.

As in other industries, measures to address private anti-competitive practices are an important adjunct to efforts to liberalize the international air transport sector. Experience indicates that the potential benefits of liberalization/freer entry in airline markets (as in other industries) will be eroded if carriers are permitted to create unwarranted market power through mergers, joint ventures and strategic alliances, or to collude or engage in predatory or other anti-competitive actions. The appropriate response to this concern is the implementation of effective competition laws or similar instruments. The sound application of competition law in this sector does not, however, involve sweeping intervention or blanket prohibition of practices such as mergers or code-sharing, as these can generate significant efficiency gains and benefits for consumers. Rather, the approach is case-by-case, aimed at preventing structural amalgamations and conduct that are harmful to competition, without coming in the way of efficient inter-lining arrangements, necessary re-structuring or pro-competitive pricing. Competition authorities also have a role to play through their advocacy functions in promoting wider policy changes in favour of competition and efficiency in the airline sector.

Despite the industry's resilience to external shocks and its ability continuously to reinvent itself, it still faces a number of policy challenges, including in taking full advantage of benefits that can flow from deregulation and liberalization. In the context of international trade, this means further clarification of the contribution that can be made by international cooperation. The current system of bilateral agreements has become more liberal over time, and has been complemented by a handful of regional agreements. The question remains whether the governance of international air transport services can be more efficiently handled at the multilateral level rather than through a network of more narrowly drawn agreements. 


\section{BIBLIOGRAPHY}

Air Transport Action Group (ATAG) (2003) The contribution of air transport to sustainable development in Africa, Study Prepared for ATAG by Oxford Economic Forecasting, Geneva: ATAG.

Arhel, P. (2004) 'Transparence tarifaire et pratiques restrictives', Répertoire de droit commercial.

Anderson, R. D. and Jenny, F. (2005) 'Competition Policy, Economic Development and the Multilateral Trading System', in Erlinda Medalla, ed., Competition Policy in East Asia (PAFTAD: forthcoming 2005), chapter 4.

Anderson, R. D. and Khosla, S. D. (1995) 'Competition Policy as a Dimension of Economic Policy: a Comparative Perspective', Industry Canada Occasional Paper 7, May, Ottawa.

Anderson, R. D., Hollander, A., Monteiro, J. and Stanbury, W.T. (1998). 'Competition Policy and Regulatory Reform in Canada, 1986-1997', Review of Industrial Organization 13 (1-2), April: 177-204.

Bailey, E. (1981) 'Contestability and the Design of Regulatory and Antitrust Policy' American Economic Review, 71(2): 178-83.

Bamberger, G. and Carlton, D. (1999) 'An empirical assessment of predation in the airline industry', unpublished manuscript.

Baumol, W. J., Panzar, J. C. and Willig, R. D. (1982) Contestable Markets and the Theory of Industry Structure, San Diego: Harcourt Brace Jovanovich.

Bingaman, A. K. (1996) Consolidation and code-sharing: antitrust enforcement in the airline industry, US Department of Justice, January 25.

Birdsall, N. and Lawrence, R. Z. (1999) 'Deep integration and trade agreements: good for developing countries?' in Inge Kaul, Isabelle Grunberg and Marc A. Stern (eds) Global Public Goods: International Cooperation in the 21st Century, New York: Oxford University Press for the United Nations Development Program.

Borenstein, S. (1990) 'Airline Mergers, Airport Dominance and Market Power', American Economic Review 80, 2, May: 400-404.

- (1992) 'The Evolution of U.S. Airline Competition', Journal of Economic Perspectives 6, 2, Spring: 45-73.

Bork, R. H. (1978) The Antitrust Paradox: A Policy at War with Itself, New York: Basic Books.

Bowen, J. and Leinbach, T. (1996), "Development and Liberalisation: The airline industry in ASEAN" in G. Hufbauer and C. Findlay (eds) Flying High: Liberalising Civil Aviation in the Asia Pacific, Washington, D.C.: Institute for International Economics.

British Airways (2004) "First Regional BA-AA Codeshares", Press Release, January 15.

Button, K. J. (1990) Airline Deregulation: An International Perspective, London: David Fulton.

Canada Transportation Act Review (2001) Vision and Balance, Final Report of the Canada Transportation Act Review Panel. Available online http://www.reviewcta-examenltc.gc.ca/english/pages/finalreport.htm. Accessed 04/03/05.

Canada, Competition Bureau (2004) Competition Bureau settles case with Air Canada, News Release, October 29.

Clarke, J. and Evenett, S. J. (2003) 'A multilateral framework for competition policy?', in State Secretariat of Economic Affairs and Simon Evenett, The Singapore Issues and the World Trading System: the Road to Cancun and Beyond, Bern: State Secretariat for Economic Affairs.

Doove, S., Gabbitas, O., Nguyen-Hong, D. and Owen, J. (2001) Price Effects of Regulation: International Air Passenger Transport, Telecommunications and Electricity Supply, Productivity Commission Staff Research Paper, Ausinfo, Canberra.

Douglas, G. W. and Miller, J. C. III (1974) Economic Regulation of Domestic Air Transport: Theory and Policy, Washington, DC: The Brookings Institution. 
Dresner, M. and Tretheway, M. (1992) 'Modelling and testing the effect of market structure on price: the case of international air transport', Journal of Transport Economics and Policy 26, 2:171-184.

Easterbrook, F. H. (1981) 'Predatory Strategies and Counterstrategies', University of Chicago Law Review 48.

Economic Council of Canada (1981) Reforming Regulation, Ottawa: Supply and Services Canada.

European Commission (EC) (2004a) Case no COMP/M.3280 - Air France/KLM, Brussels. Available online http://europa.eu.int/comm/competition/mergers/cases/decisions/m3280_en.pdf. Accessed 04/03/05.

- (2004b) 'Concerning the revision and possible prorogation of Commission Regulation 1617/93 on the application of Article 81(3) to certain categories of agreements and concerted practices concerning consultations on passenger tariffs on scheduled air services and slot allocation at airports, Brussels', DG Competition Consultation Paper. Available online http://europa.eu.int/comm/competition/antitrust/ others/consultation_paper_en.pdf). Accessed 04/03/05.

- (2005a) 'Concerning the revision and possible prorogation of Commission Regulation 1617/93 on the application of Article 81(3) to certain categories of agreements and concerted practices concerning consultations on passenger tariffs on scheduled air services and slot allocation at airports', Brussels: DG Competition Discussion Paper. Available online http://europa.eu.int/comm/competition/antitrust/others/ discussion_paper_en.pdf. Accessed 12/05/05.

- (2005b) 'Developing the agenda for the Community's external aviation policy', Brussels: Communication from the Commission, $\operatorname{COM}(2005) 79$ final, 11 March.

- (2005c) 'Air transport: an ambitious external relations agenda', Brussels: Press release, IP/05/288, 14 March.

Evenett, S. J. (2003) Study on Issues Relating to a Possible Multilateral Framework on Competition Policy, Study prepared for the WTO Working Group on the Interaction between Trade and Competition Policy, (Geneva: WTO, WT/WGTCP/W/228).

Findlay, C. (1985) The Flying Kangaroo: an endangered species, Sydney: Allen and Unwin.

- (2003) 'Plurilateral agreements on trade in air transport services: the US model', Journal of Air Transport Management 9, 211-220.

Fones, R. W. (1997) Predation in the Airline Industry, Remarks before the American Bar Association Forum on Air and Space Law, June 12.

Forsyth, P. (1998) 'The gains from the liberalisation of air transport - a review of reform', Journal of Transport Economics and Policy 32, 1: 73-92.

Gillen, D. and Lall, A. (2004) 'Competitive Advantage of Low Cost Carriers: Some Implications for Airports', Journal of Air Transport Management 10, 1: 41-50.

Goldstein, A. (2001) 'Infrastructure Development and Regulatory Reform in Sub-Saharan Africa: The Case of Air Transport', The World Economy 24, 2: 221-248.

Gonenc, R. and Nicoletti, G. (2000) 'Regulation, market structure and performance in air passenger transportation', Working Paper no. 254, ECO/WKP (2000) 27, Economics Department, Paris: OECD.

- (2001) 'Regulation, market structure and performance in air passenger transportation', OECD Economic Studies 32: 11-98, Paris: OECD.

Havel, B. (1997) In Search of Open Skies: Law and Policy for a New Era in International Aviation, Amsterdam: Kluwer Law.

Hooper, P. (2004) 'The competitive Position of South East Asia's new and evolving airlines', mimeo, Bangkok: ICAO.

International Civil Aviation Organization (2003) The World of Civil Aviation 2001-2005, Montreal: ICAO. 
Jordan, W. A. (1970) Airline Regulation in America: Effects and Imperfections, Baltimore: The Johns Hopkins Press.

- (1972) 'Producer Protection, Prior Market Structure and the Effects of Government Regulation', Journal of Law and Economics XV, April: 151-176.

- (1975). 'Air Transportation Markets: Definitional Confusion' Journal of Law and Economics (Winter), Vol. 33-56.

- (1982) Performance of Regulated Canadian Airlines in Domestic and Transborder Operations, Ottawa: Consumer and Corporate Affairs Canada.

- $\quad$ (1988) 'Problems Stemming from Airline Mergers and Acquisitions', Transportation Journal, Summer: 930.

- (1997) 'Startup Airlines -- Safe or Unsafe?', in Proceedings of the 39th Annual Meeting of the Transportation Research Forum (Montreal, Canada), pp. 377-400.

- $\quad$ (2002) 'Adverse Effects of Mergers on Airline Performance - Evidence from Canadian Airlines International, Ltd', mimeo.

- (2005) 'Airline Entry Following U.S. Deregulation: The Definitive List of Startup Passenger Airlines, 19792003', Paper prepared for presentation at the 2005 Annual Meeting of the Transportation Research Forum, Washington, D.C., March 6-8.

Joskow, A. S., Werden, G. J. and Johnson, R. L. (1994) 'Entry, exit and performance in airline markets', International Journal of Industrial Organization 12: 457-471.

Kahn, A. E. (2002) 'Airline Deregulation', The Concise Library of Economics, Indianapolis: Liberty Fund, Inc.

Lall, A. (2005) 'Predatory pricing; Still a rare occurance?' in Peter Forsyth, David Gillen, Otto Mayer and HansMartin Niemeier (eds), Competition versus Predation in Aviation Markets: A survey of experience in NorthAmerica, Europe and Australia. London: Aldgate Publishing.

Levenstein, M. and Suslow, V. (2001) 'Private international cartels and their effect on developing countries', background paper for the World Bank's World Development Report 2000-2001, 9 January. Available online http://www-unix.oit.umass.edu/ maggiel /WDR2001.pdf. Accessed 27/04/05.

Levine, M. E. (1987) 'Airline Competition in Deregulated Markets: Theory, Firm Strategy, and Public Policy', Yale Journal on Regulation 4: 393-494.

Liu, A., Wall, G. and Westlake, J. (2000) 'Marketing through frequent flier programmes: the example of China Airlines', Tourism Economics 6, 3: 233-249.

Loy, F. (1996) 'US Civil Aviation Policy: Questioning the Conventional Wisdom', in G. Hufbauer and C. Findlay (eds), Flying High: Liberalizing Civil Aviation in the Asia Pacific, Washington, D.C.: Institute for International Economics.

McDonald, B. J. (2004) Transportation Update, Remarks to the ABA Section of Antitrust Law Transportation Industry Committee, Washington, DC, March 31.

Micco, A. and Serebrisky, T. (2004), 'Infrastructure, competition regimes and transport costs', World Bank Policy Research Paper No. 3355, Washington, D.C.: World Bank.

Milgrom, P. and Roberts, J. (1982) 'Predation, Reputation and Entry Deterrence' Journal of Economic Theory 27: 280-312.

Milner, C., Morrissey, O. and Rudaheranwa, N. (1998) 'Protection, Trade Policy and Transport Costs: Effective Taxation of Ugandan exporters', Centre for Research in Economic Development and International Trade (CREDIT) Research Paper no. 98/13, CREDIT, University of Nottingham.

Monti, M. (2003) Recent developments in European air transport law and policy Brussels, Belgium: European Air Law Association, 15th Annual Conference, 6 November. 
Morrison, S.A. and Winston, C. (1989) "Enhancing the performance of the deregulated air transportation system," Brookings Papers on Economic Activity: Microeconomics, pp. 61-112.

- $\quad$ (1990) 'The Dynamics of Airline Pricing and Competition', American Economic Review 80, 2, May: 389393.

Nannes, J. M. (1999) The importance of entry conditions in analyzing airline antitrust issues, US Department of Justice, July 20.

Organization for Economic Co-operation and Development (OECD) (1999) 'Regulatory Reform in International Air Cargo Transportation', DSTI/DOT (1999), Paris: OECD.

Oum, T.H. and Yu, C. (1995) 'A productivity comparison of the world's major airlines', Journal of Air Transport Management 2: 181-195.

- (1998) Winning Airlines - Productivity and Cost Competitiveness of the World's Major Airlines, Amsterdam: Kluwer Academic Publishers.

Owen, B. M. (2003) Competition Policy in Latin America, Stanford Law School, John M. Ohlin Program in Law and Economics, Working Paper 268, October.

Ross, T. W. and Stanbury, W.T. (2001) Policy Proposals for Enhancing Competition in Canadian Airline Markets, Report prepared for the Canada Transportation Act Review.

Stanbury, W.T. (1989) 'Reforming Direct Regulation in Canada' in K.W. Button and Dennis Swann (eds.) The Age of Regulatory Reform (Oxford: Clarendon Press), pp. 49-78.

Stigler, G. J. (1971) 'The Theory of Economic Regulation', Bell Journal of Economics and Management Science 2, Spring: 3-21.

Stragier, J. (2002) EC Competition Policy in the Aviation Sector: State of Play and Outlook (Paper prepared for the Annual Conference of the Guild of European Business Travel Agents (GEBTA), Lisbon, 22 March).

US Department of Justice (2001) Justice Department Urges [Department of Transportation] to Impose Conditions on American Airlines/British Airways Alliance (Press Release, 17 December).

US Department of Justice and Federal Trade Commission (1997) Antitrust Guidelines on Horizontal Mergers, Washington, D.C.: Department of Justice.

Willig, R. D. (1991) 'Antitrust Lessons from the Airline Industry: the DOJ Experience', Antitrust Law Journal 60 , Issue 2 .

Winston, C. (1998) 'US Industry Adjustment to Economic Deregulation', Journal of Economic Perspectives 12, 3, Summer: 89-110.

World Trade Organization (WTO) (2001) 'Air Transport Services', in Guide to the GATS: An overview of issues for further liberalization of Trade in Services, Geneva: WTO.

- (2004) World Trade Report, Geneva: WTO. 


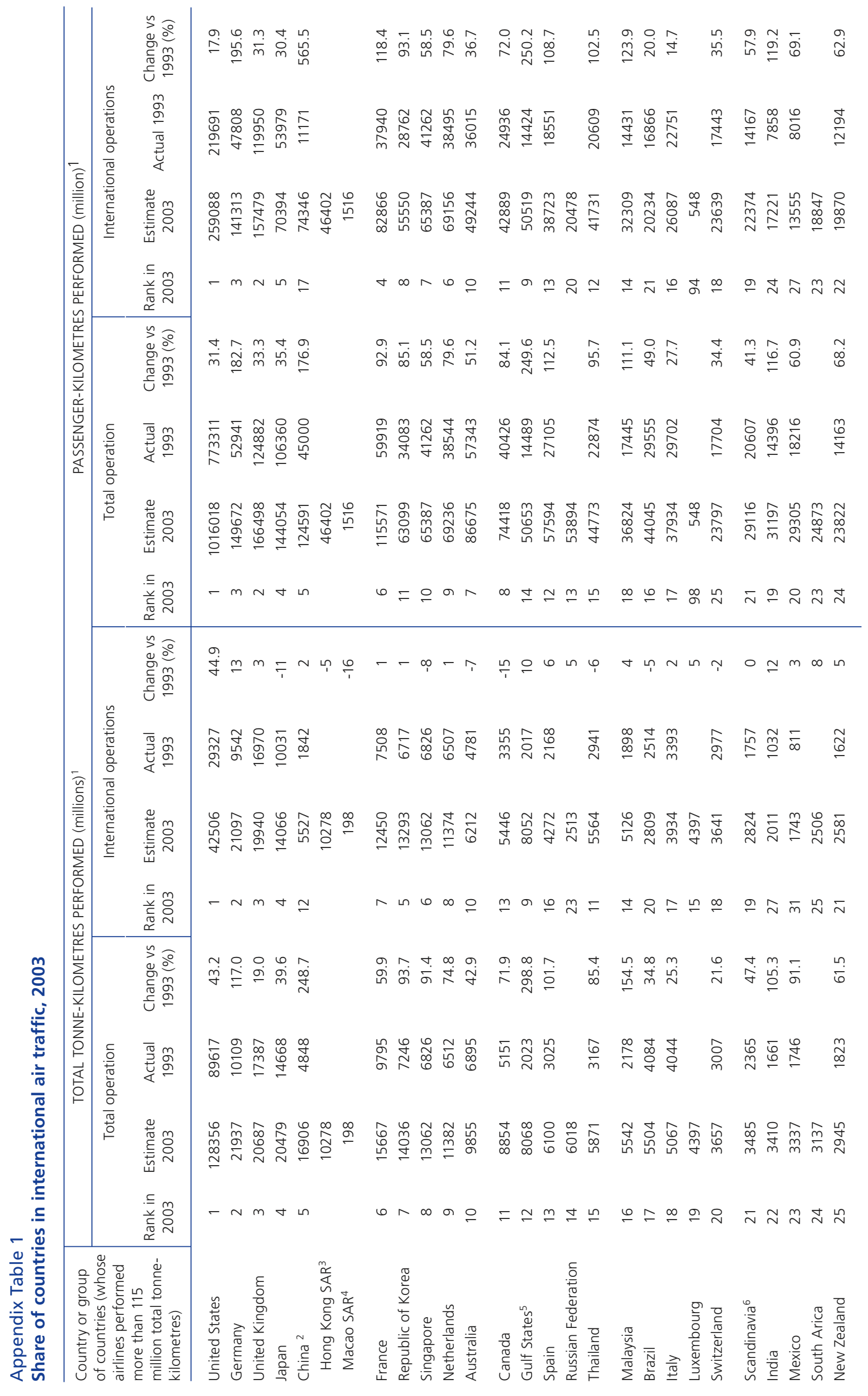




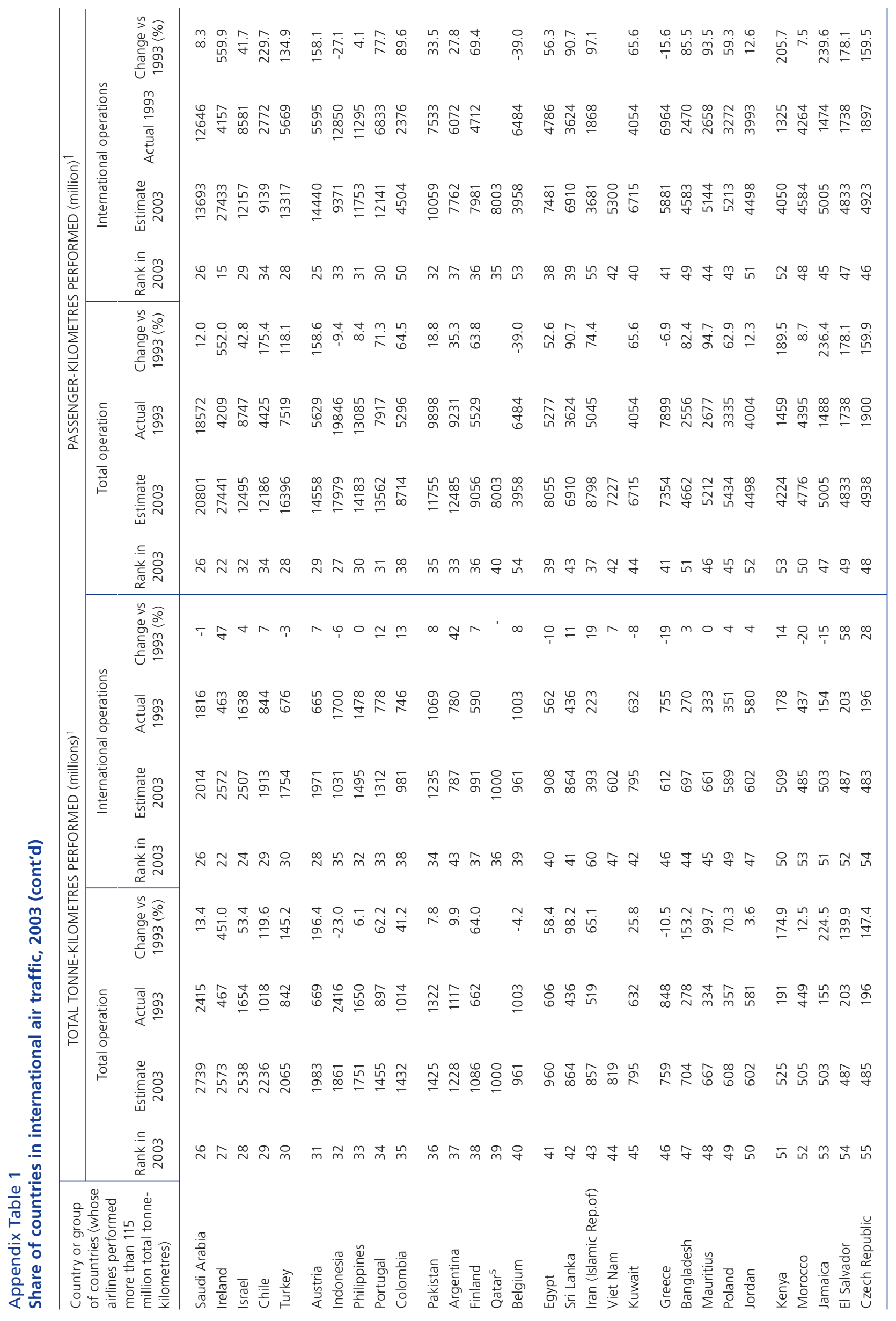




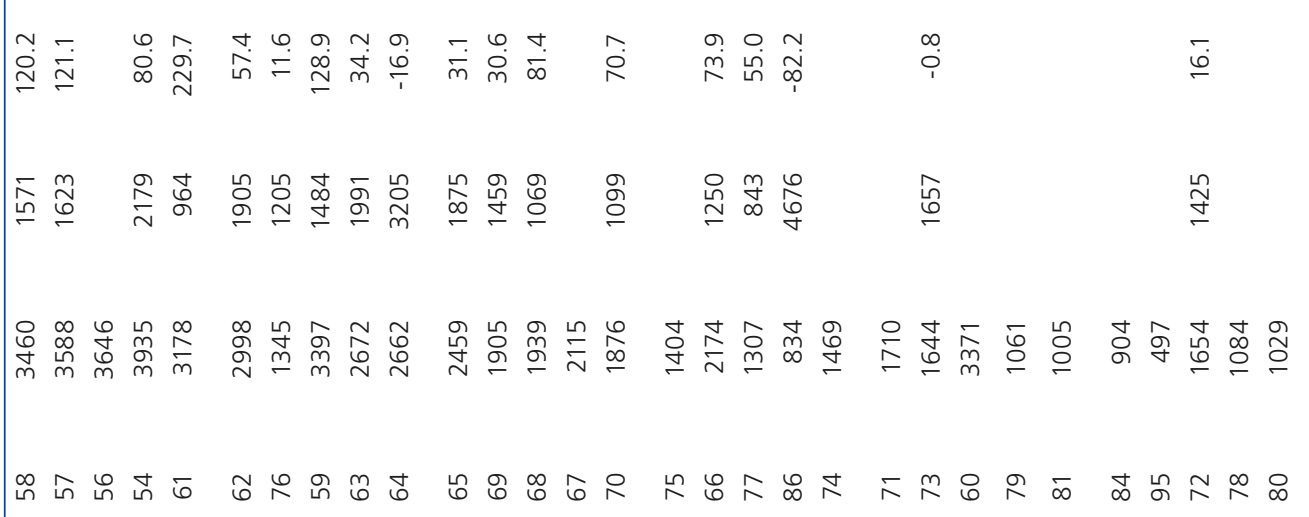

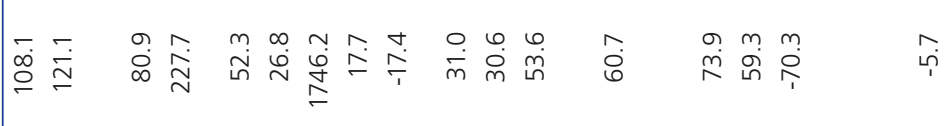

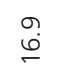

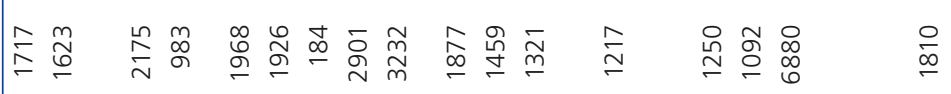

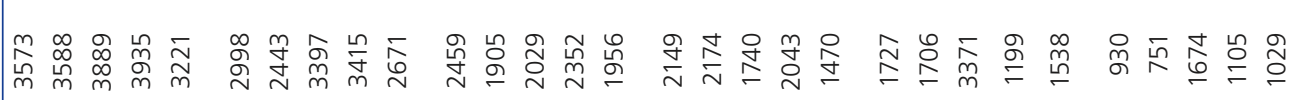

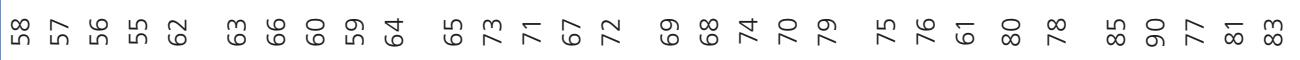

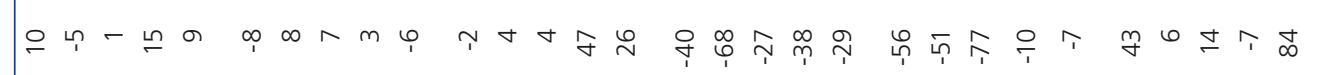

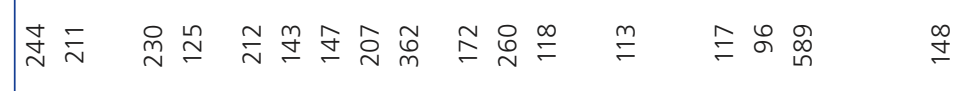

$\stackrel{\infty}{\infty}$

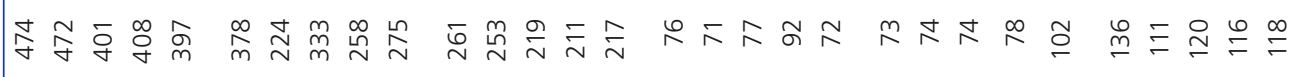

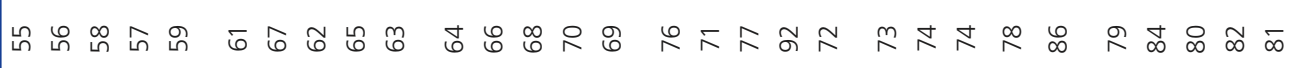

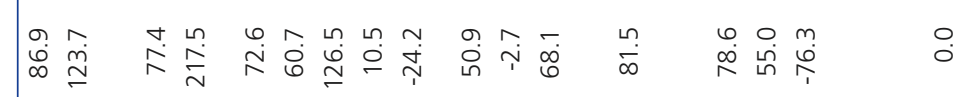

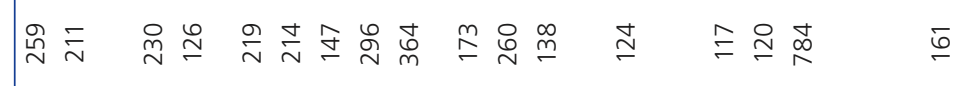

㑊

$\stackrel{\infty}{\infty}$

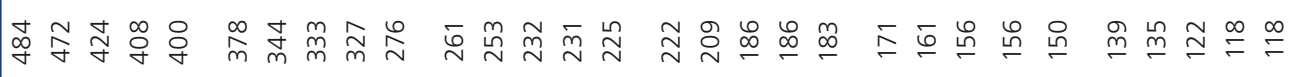

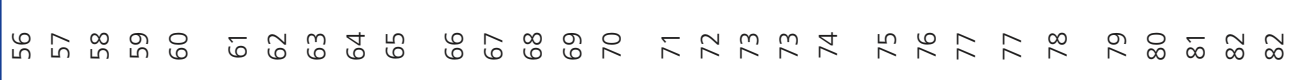

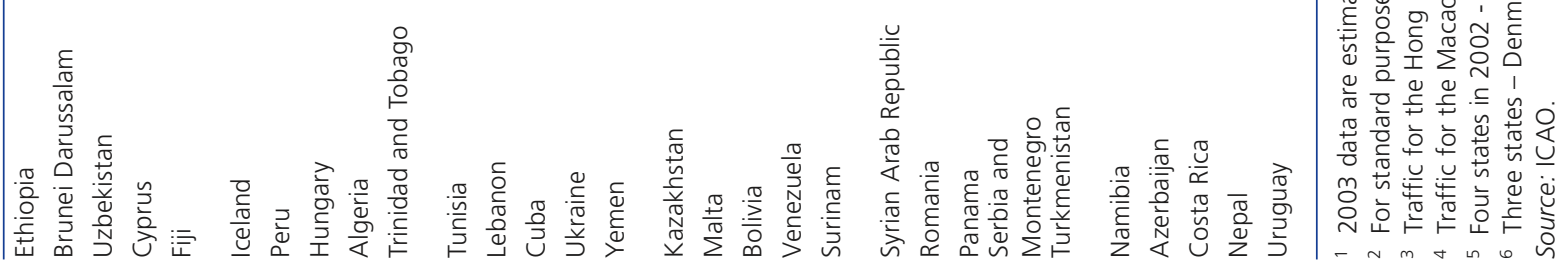




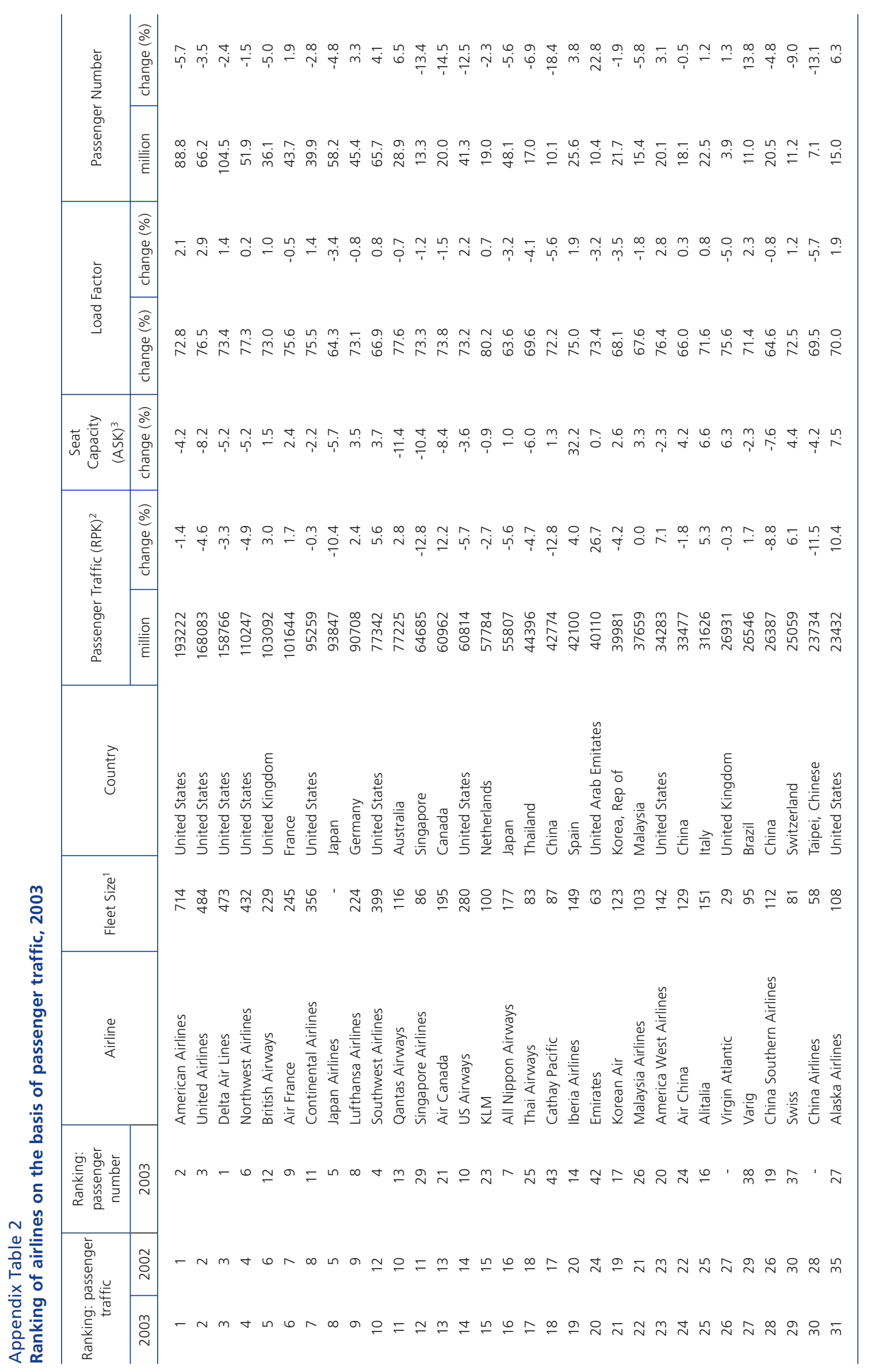




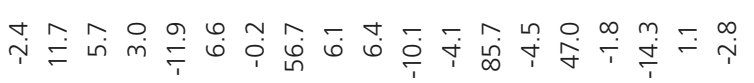

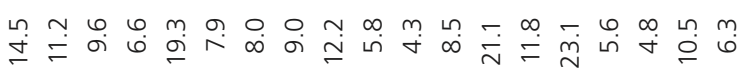



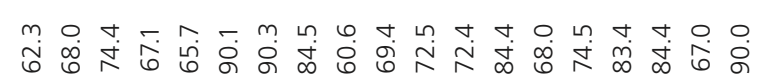

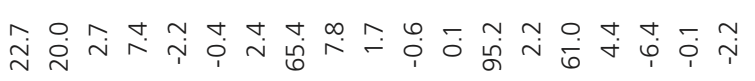

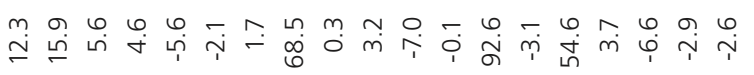

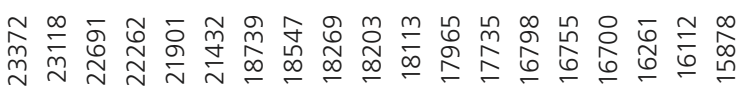

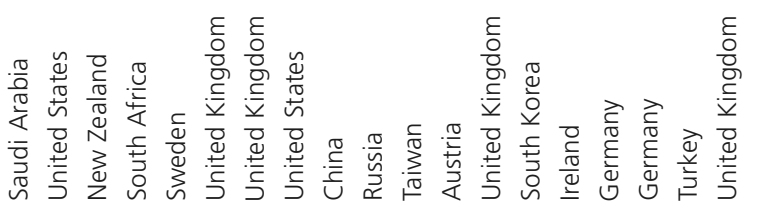

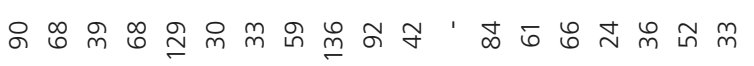

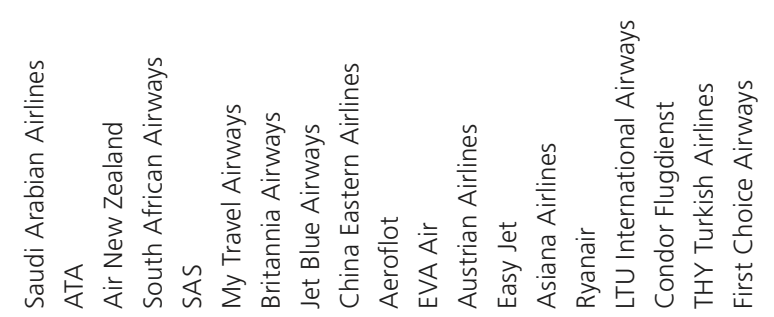

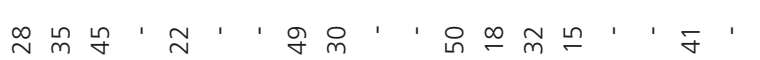

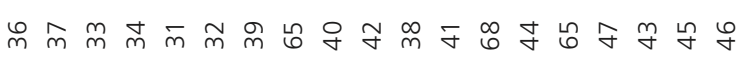

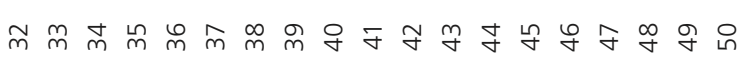

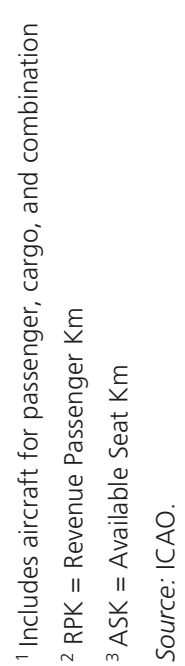


Appendix Table 3

Ranking of airlines in terms of cargo traffic, 2002

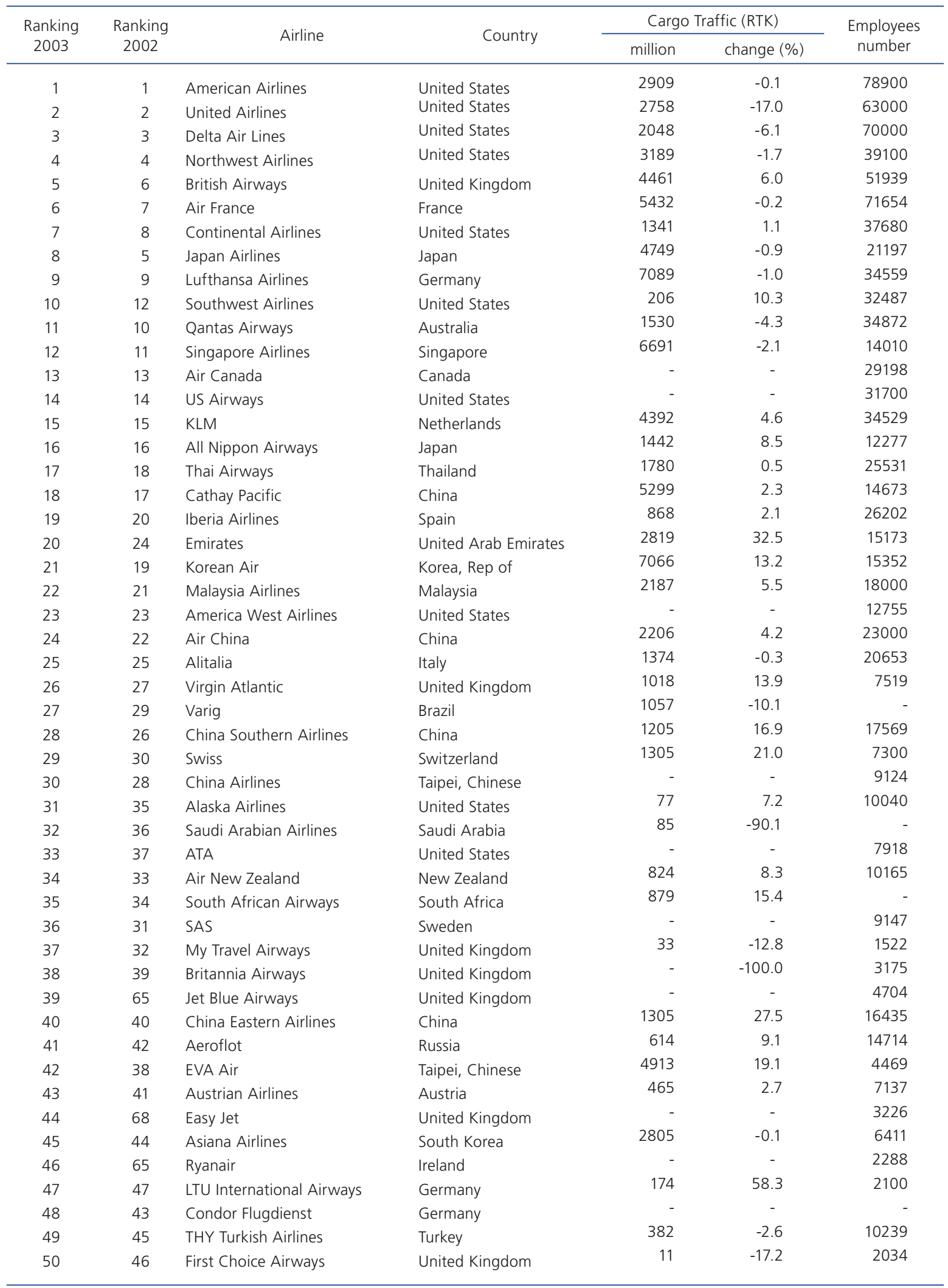

Source: ICAO 


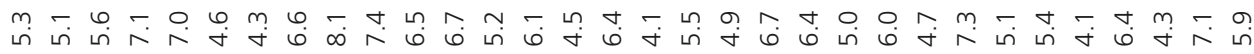

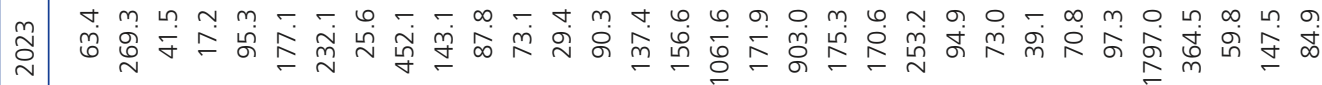

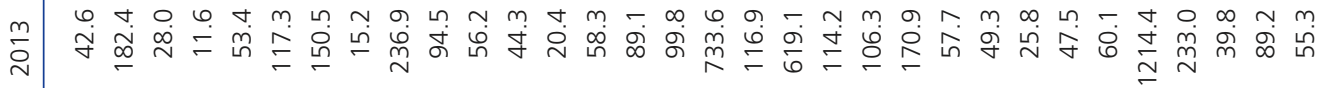

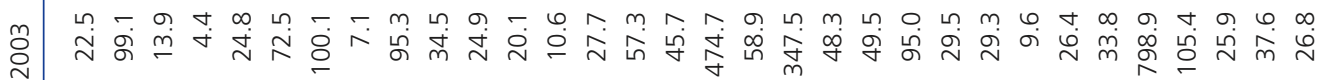

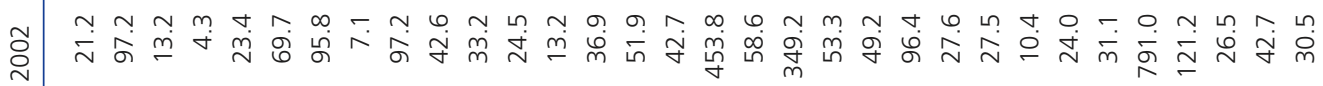

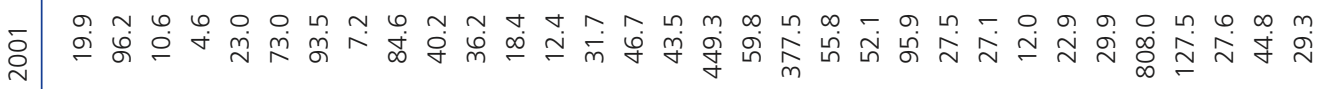

ஓ

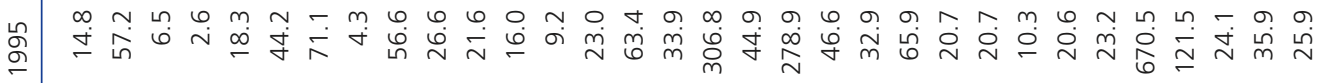

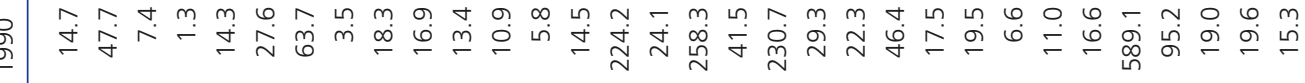

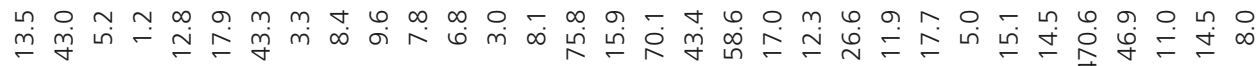

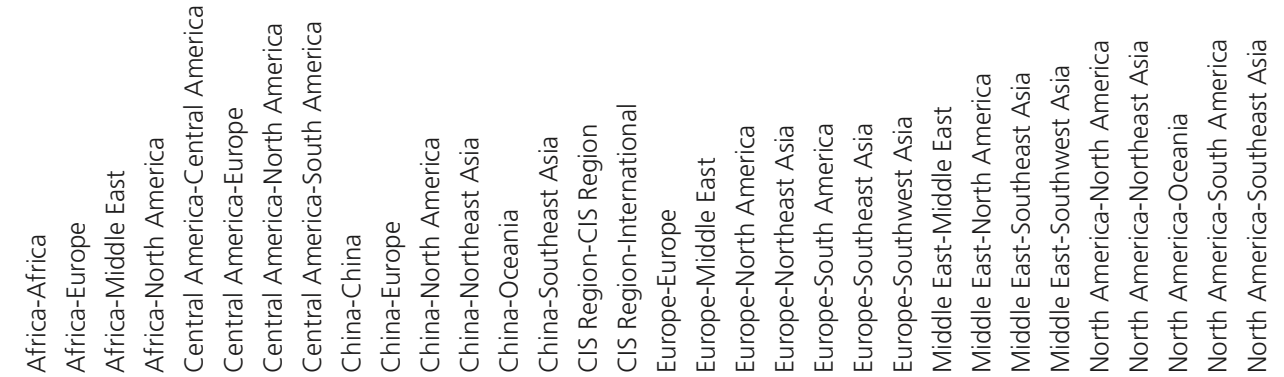




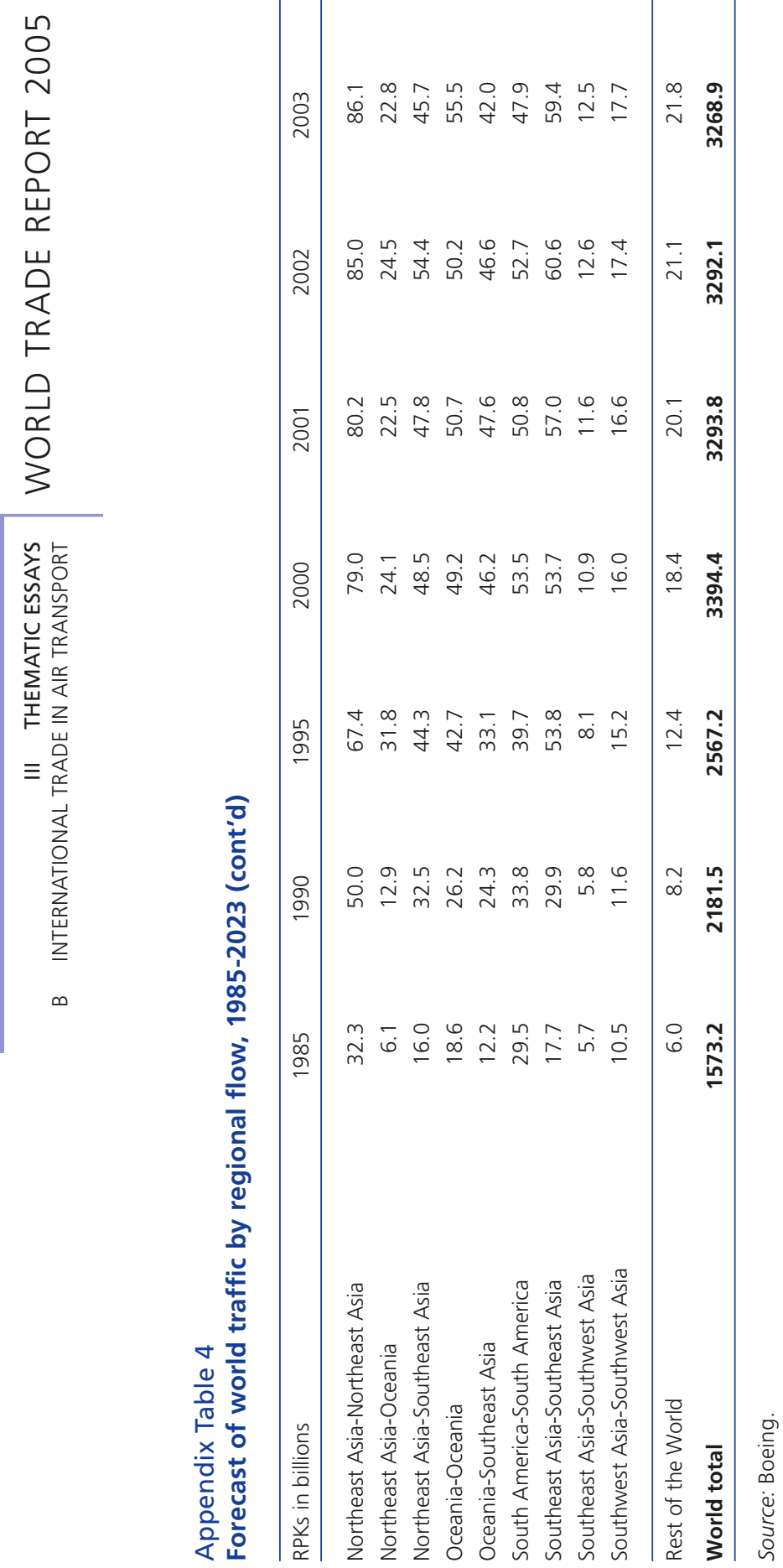

